Prepared in cooperation with the Bureau of Land Management,

Nevada Department of Wildlife, and U.S. Fish and Wildlife Service

\title{
A Hierarchical Integrated Population Model for Greater Sage-Grouse (Centrocercus urophasianus) in the Bi-State Distinct Population Segment, California and Nevada
}

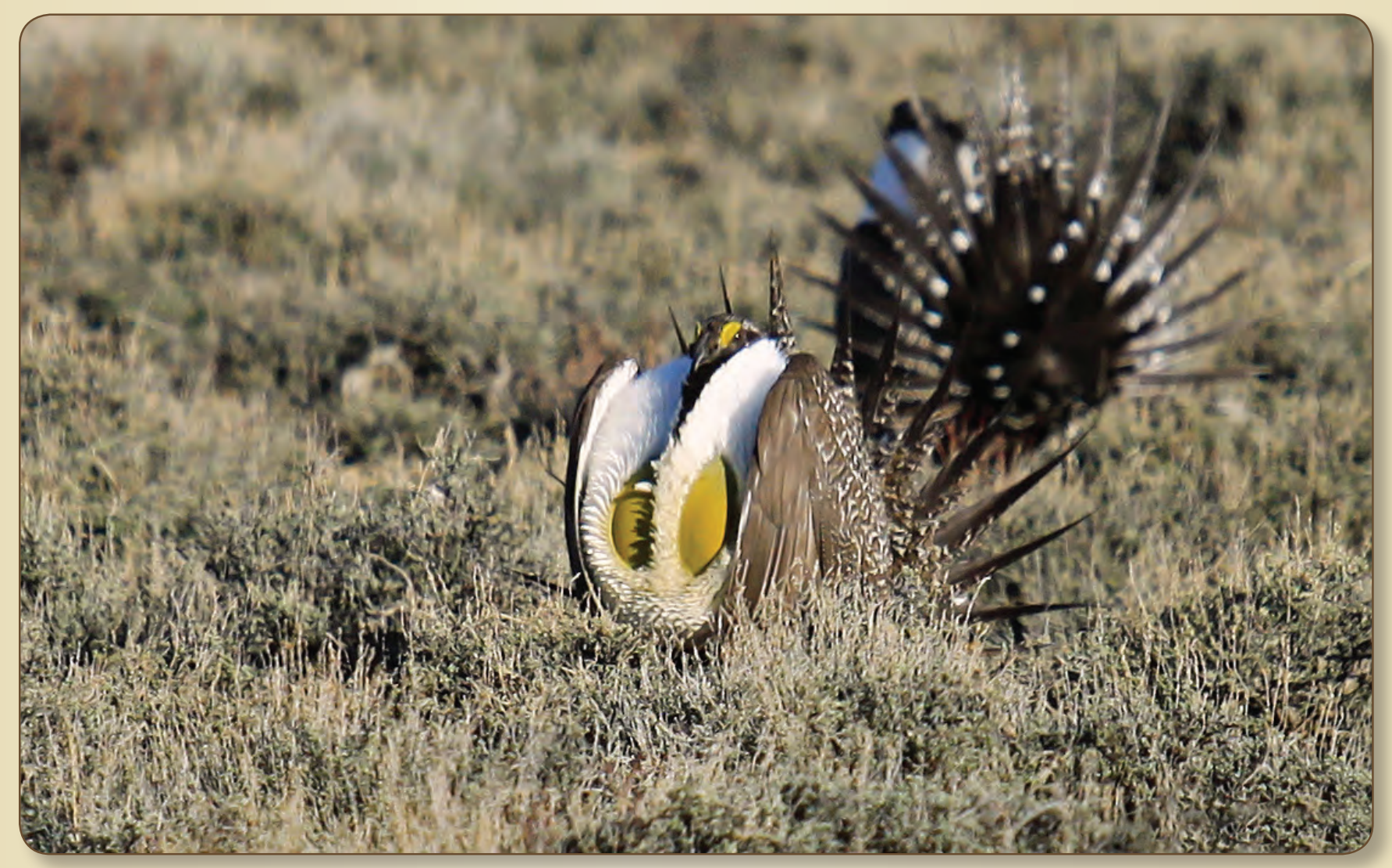

Open-File Report 2014-1165

U.S. Department of the Interior U.S. Geological Survey 
Cover: Photograph of two male greater sage-grouse performing a courtship display on a lek in Nevada. Photograph courtesy of Tatiana Gettleman. 


\section{A Hierarchical Integrated Population Model for Greater Sage-Grouse (Centrocercus urophasianus) in the Bi-State Distinct Population Segment, California and Nevada}

By Peter S. Coates, Brian J. Halstead, Erik J. Blomberg, Brianne Brussee, Kristy B. Howe, Lief Wiechman, Joel Tebbenkamp, Kerry P. Reese, Scott C. Gardner, and Michael L. Casazza

Prepared in cooperation with the Bureau of Land Management, Nevada Department of Wildlife, and U.S. Fish and Wildlife Service

Open-File Report 2014-1165

U.S. Department of the Interior

U.S. Geological Survey 


\section{U.S. Department of the Interior \\ SALLY JEWELL, Secretary}

\section{U.S. Geological Survey \\ Suzette M. Kimball, Acting Director}

U.S. Geological Survey, Reston, Virginia: 2014

For more information on the USGS—-the Federal source for science about the Earth, its natural and living resources, natural hazards, and the environment-visit

http://www.usgs.gov or call 1-888-ASK-USGS

For an overview of USGS information products, including maps, imagery, and publications, visit http://www.usgs.gov/pubprod

To order this and other USGS information products, visit $h$ ttp://store.usgs.gov

Coates, P.S., Halstead, B.J., Blomberg, E J., Brussee, B., Howe, K.B., Wiechman, L., Tebbenkamp, J., Reese, K.P., Gardner, S.C., and Casazza, M.L., 2014, A hierarchical integrated population model for greater sage-grouse (Centrocercus urophasianus) in the Bi-State Distinct Population Segment, California and Nevada: U.S. Geological Survey Open-File Report 2014-1165, 34 p., http://dx.doi.org/10.3133/ofr20141165..

ISSN 3221-1258 (online)

Any use of trade, product, or firm names is for descriptive purposes only and does not imply endorsement by the U.S. Government.

Although this report is in the public domain, permission must be secured from the individual copyright owners to reproduce any copyrighted material contained within this report. 


\section{Contents}

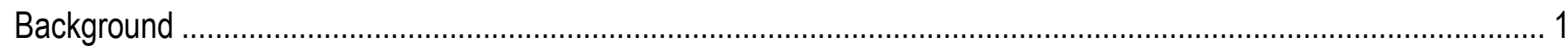

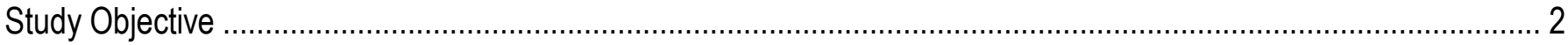

Study Area

Methods

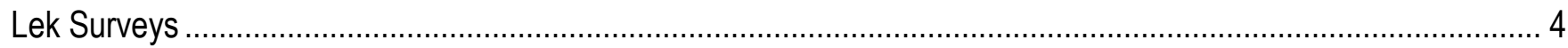

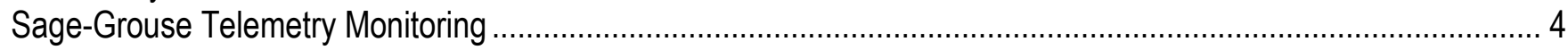

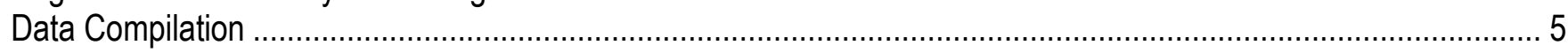

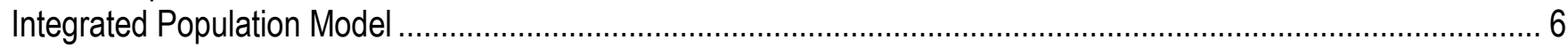

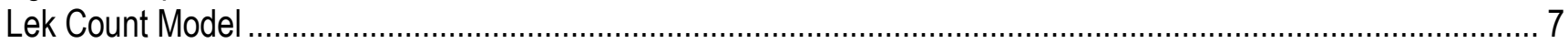

Yearling and Adult Survival Model........................................................................................................... 8

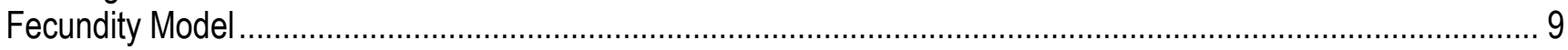

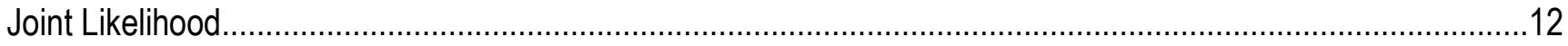

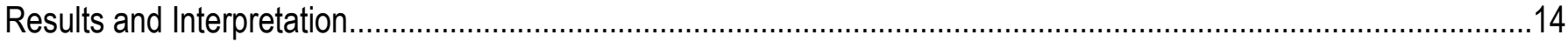

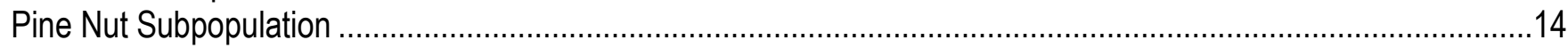

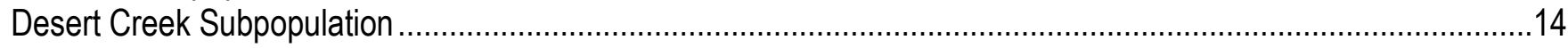

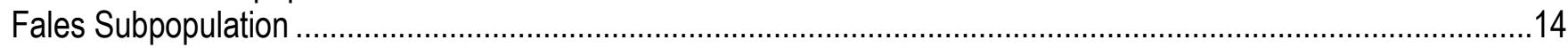

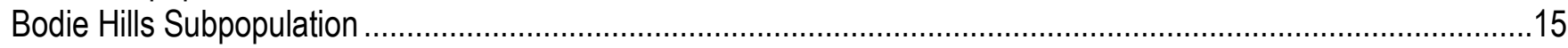

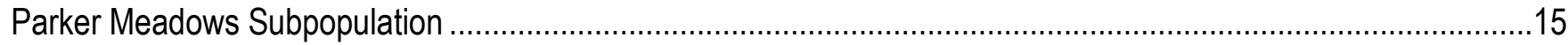

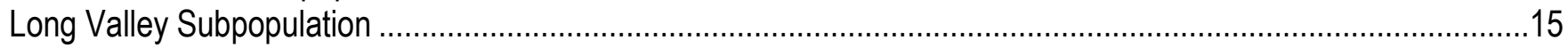

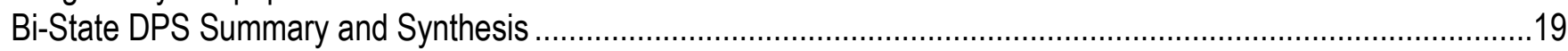

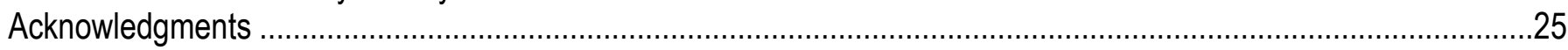

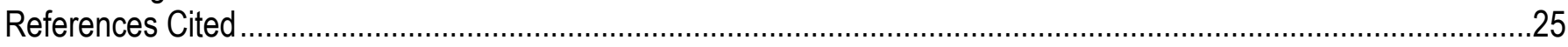

Appendix A. Summary of Derived Posterior Distributions for Greater Sage-Grouse (Centrocercus urophasianus)

Population Vital Rates by Subpopulation within the Bi-State Distinct Population Segment Study Area, 2003-12.......27

Appendix B. Summary of Derived Posterior Distributions for Greater Sage-Grouse (Centrocercus

urophasianus)Population Vital Rates by Year, 2003-12 .............................................................................30

\section{Figures}

Figure 1. Schematic map showing location of the greater sage-grouse (Centrocercus urophasianus)

Bi-State Distinct Population Segment (DPS) study area, California and Nevada

Figure 2. Diagram showing demographic components of the integrated population model for greater sage-grouse in the Bi-State Distinct Population Segment study area, California and Nevada .....

Figure 3. Diagram showing integrated population model [modified from Kéry and Shaub (2012)] for greater sage-grouse in the Bi-State Distinct Population Segment study area, California and Nevada

Figure 4. Graphs showing estimated number of male sage-grouse per lek (solid line) and lek observations (dashed line), Bi-State Distinct Population Segment study area, California and Nevada, 2003-12.

Figure 5. Graphs showing annual lek attendance counts (solid line) and estimates (dashed line) across all

Bi-State Distinct Population Segment study area sites, California and Nevada, 2003-12.

Figure 6. Graphs showing population growth rate $(\lambda)$ for each monitored site $(A-F)$, Distinct Population

Segment study area, California and Nevada, 2003-12

Figure 7. Graph showing annual population growth rate $(\lambda)$ across all Bi-State Distinct Population

Segment study area sites, California and Nevada, 2003-12 
Figure 8. Graphs showing In(odds ratio) of population increase to decrease for each monitored site (A-F), Bi-State Distinct Population Segment study area, California and Nevada, 2003-12

Figure 9. Graph showing In(odds ratio) of increase to decrease across all Bi-State Distinct Population Segment study area subpopulations, California and Nevada, 2003-12.

\section{Tables}

Table 1. Summary of lek survey data averaged across years for greater sage-grouse (Centrocercus urophasianus) in the Bi-State Distinct Population Segment study area, California and Nevada, 2003-12

Table 2. Summary of posterior distributions of derived population vital rate parameters for greater sage-grouse (Centrocercus urophasianus) in the Bi-State Distinct Population Segment study area, California and Nevada, 2003-12.

\section{Conversion Factors and Datum}

\section{Conversion Factors}

\begin{tabular}{lcl}
\multicolumn{1}{c}{ SI to Inch/Pound } & & \\
& Bultiply & To obtain \\
\hline meter $(\mathrm{m})$ & Length & foot $(\mathrm{ft})$ \\
\hline & 3.281 & \\
\hline square kilometer $\left(\mathrm{km}^{2}\right)$ & Area & acre \\
square kilometer $\left(\mathrm{km}^{2}\right)$ & 247.1 & square mile $\left(\mathrm{mi}^{2}\right)$ \\
\hline
\end{tabular}

\section{Datum}

Vertical coordinate information is referenced to the insert North American Vertical Datum of 1988 (NAVD 88).

Elevation, as used in this report, refers to distance above the vertical datum.

\section{Acronyms and Abbreviations}

CDFW California Department of Fish and Wildlife

CI confidence interval

CRI credible interval

DPS Distinct Population Segment

GPS Global Positioning System

IPM integrated population modeling

PMU population management unit

PTT Platform Transmitter Terminal

NDOW Nevada Department of Wildlife

USGS U.S. Geological Survey

VHF Very High Frequency 


\section{A Hierarchical Integrated Population Model for Greater Sage-Grouse (Centrocercus urophasianus) in the Bi-State Distinct Population Segment, California and Nevada}

By Peter S. Coates ${ }^{1}$, Brian J. Halstead', Erik J. Blomberg², Brianne Brussee ${ }^{1}, K^{2}$ risty B. Howe ${ }^{1}$, Lief Wiechman ${ }^{3}$, Joel Tebbenkamp ${ }^{4}$, Kerry P. Reese ${ }^{4}$, and Michael L. Casazza ${ }^{1}$

\section{Background}

Greater sage-grouse (Centrocercus urophasianus, hereafter referred to as "sage-grouse") are endemic to sagebrush (Artemisia spp.) ecosystems throughout Western North America. Populations of sage-grouse have declined in distribution and abundance across the range of the species (Schroeder and others, 2004; Knick and Connelly, 2011), largely as a result of human disruption of sagebrush communities (Knick and Connelly, 2011). The Bi-State Distinct Population Segment (DPS) represents sage-grouse populations that are geographically isolated and genetically distinct (Benedict and others, 2003; Oyler-McCance and others, 2005) and that are present at the extreme southwestern distribution of the sage-grouse range (Schroeder and others, 2004), straddling the border of California and Nevada. Subpopulations of sage-grouse in the DPS may be at increased risk of extirpation because of a substantial loss of sagebrush habitat and lack of connectivity (Oyler-McCance and others, 2005). Sage-grouse in the Bi-State DPS represent small, localized breeding populations distributed across $18,325 \mathrm{~km}^{2}$.

The U.S. Fish and Wildlife Service currently (2014) is evaluating the Bi-State DPS as threatened or endangered under the Endangered Species Act of 1973, independent of other sage-grouse populations. This DPS was designated as a higher priority for listing than sage-grouse in other parts of the species' range (U.S. Department of the Interior, 2010). Range-wide population analyses for sagegrouse have included portions of the Bi-State DPS (Sage and Columbian Sharp-tailed Grouse Technical Committee 2008; Garton and others, 2011). Although these analyses are informative, the underlying data only represent a portion of the DPS and are comprised of lek count observations only. A thorough examination of population dynamics and persistence that includes multiple subpopulations and represents the majority of the DPS is largely lacking. Furthermore, fundamental information on population growth rate (i.e., finite rate of change, $\lambda$ ) and specific demographic parameters that explain sources of variation in $\lambda$ within different subpopulations would be valuable for making conservation and management decisions for this DPS.

\footnotetext{
${ }^{1}$ U.S. Geological Survey, Western Ecological Research Center, 800 Business Park Drive, Suite D, Dixon, California 95620.

${ }^{2}$ Department of Wildlife, Fisheries, and Conservation Biology, University of Maine.

${ }^{3}$ U.S. Fish \& Wildlife Service, Mountain-Prairie Region.

${ }^{4}$ Department of Fish and Wildlife Sciences, University of Idaho.
} 
During 2003-12, agencies and universities collaborated to conduct extensive monitoring of sagegrouse populations within the Bi-State DPS. Data regarding lek attendance, movement, and survival of sage-grouse across multiple life stages were documented. Specifically, sage-grouse from nearly all subpopulations were marked and tracked across multiple seasons using radio-telemetry techniques. A hierarchical integrated population modeling (IPM) approach was used to derive demographic parameters for the Bi-State DPS using the large amount of data collected over a 10-year period. This modeling approach allows integration of multiple data sources to inform population growth rates and population vital rates for the Bi-State DPS overall, as well as for individual subpopulations. These models are more informative than other models because they integrate inputs of demographic data (for example, survival and fecundity rates) and survey data (for example, lek observations). The findings here will help characterize population growth rates within the Bi-State DPS.

\section{Study Objective}

This report describes the IPM, which is the first step of a multi-step population analysis. The overall study objective was to develop a stage-based, stochastic population model that included age structure for the Bi-State DPS. A major component of this objective was to compile and quantify multiple sources of survey and demographic data collected over a 10-year period. Recent developments in Bayesian statistical analysis provide the most useful framework to integrate multiple data sources and refine parameter estimation (Kéry and Shaub, 2012). Therefore, we integrated our data into a Bayesian modeling framework with the purpose of deriving numerous population parameters to better understand population dynamics in the Bi-State DPS. In the first step of the analysis, we derived these parameters specifically to: (1) estimate population growth rates $(\lambda)$ for the Bi-State; $(2)$ estimate population vital rates for each life history stage; (3) identify differences in rates between age classes; (4) identify differences in rates between subpopulations; and (5) identify temporal patterns in population vital rates and $\lambda$. A second step of this analysis will be carried out to estimate the relative importance of specific vital rates (for example, adult survival, nest success, chick survival) to sage-grouse persistence using sensitivity, elasticity, and retrospective correlation analyses. In a final step, environmental covariates will be fit to the estimated rates. This report provides methods and results for the first step of the analysis only. The report findings will be useful as decision support for conservation and management of the Bi-State DPS, as well as for specific subpopulations.

\section{Study Area}

The study area encompasses 18,325 $\mathrm{km}^{2}$ of land in Mono, Alpine, and Inyo Counties, California, and Carson City, Douglas, Esmeralda, Lyon, and Mineral Counties, Nevada. The Bi-State DPS consisted of six PMUs_-Pine Nut Mountains, Desert Creek-Fales, Mount Grant, Bodie Hills, South Mono, and White Mountains. The PMU boundaries were delineated by state wildlife management agencies using land-tenure and ecologically-based rationale. For this study, we monitored sage-grouse within 6 subpopulations (Pine Nut, Desert Creek, Fales, Bodie Hills, Parker Meadows, and Long Valley) across 4 of those PMUs (fig. 1). No subpopulations were monitored within the Mount Grant and White Mountain PMU. Based on existing knowledge of sage-grouse movement within the Bi-State DPS, we assumed that movement between these subpopulations was negligible or nonexistent. The number of subpopulations and their spatial distribution provided a reliable representation of 
demography for the Bi-State DPS. Elevation ranged from 1,386 to 4,344 m. Wyoming big sagebrush (Artemisia tridentata ssp. wyomingensis) and black sagebrush (Artemisia nova) dominated landscapes at low elevations below about 2,100 m, whereas mountain big sagebrush (Artemisia tridentata ssp. vaseyana) and low sagebrush (Artemisia arbuscula) dominated high elevations. Other common shrubs in sagebrush communities included rabbitbrush (Chrysothamnus spp.), Mormon tea (Ephedra viridis), snowberry (Symphoricarpos spp.), western serviceberry (Amelanchier alnifolia), and antelope bitterbrush (Purshia tridentata). Although sagebrush communities within the Bi-State DPS were typical of those present elsewhere in the Great Basin, this region had relatively greater amounts of singleleaf pinyon (Pinus monophylla; hereafter referred to as "pinyon") and Utah juniper (Juniperus osteosperma; hereafter referred to as "juniper"). Jeffery pine (Pinus jeffreyi) and other conifer species were present at some sites, but were less abundant than pinyon and juniper. Common grasses included needle and thread (Hesperostipa comata), Indian ricegrass (Achnatherum hymenoides), and bottlebrush squirreltail (Elymus elymoidess); and common forbs included phlox (Phlox spp.), lupine (Lupinus spp.), buckwheat (Eriogonum spp.), mule-ears (Wyethia spp.), and hawksbeard (Crepis spp.).

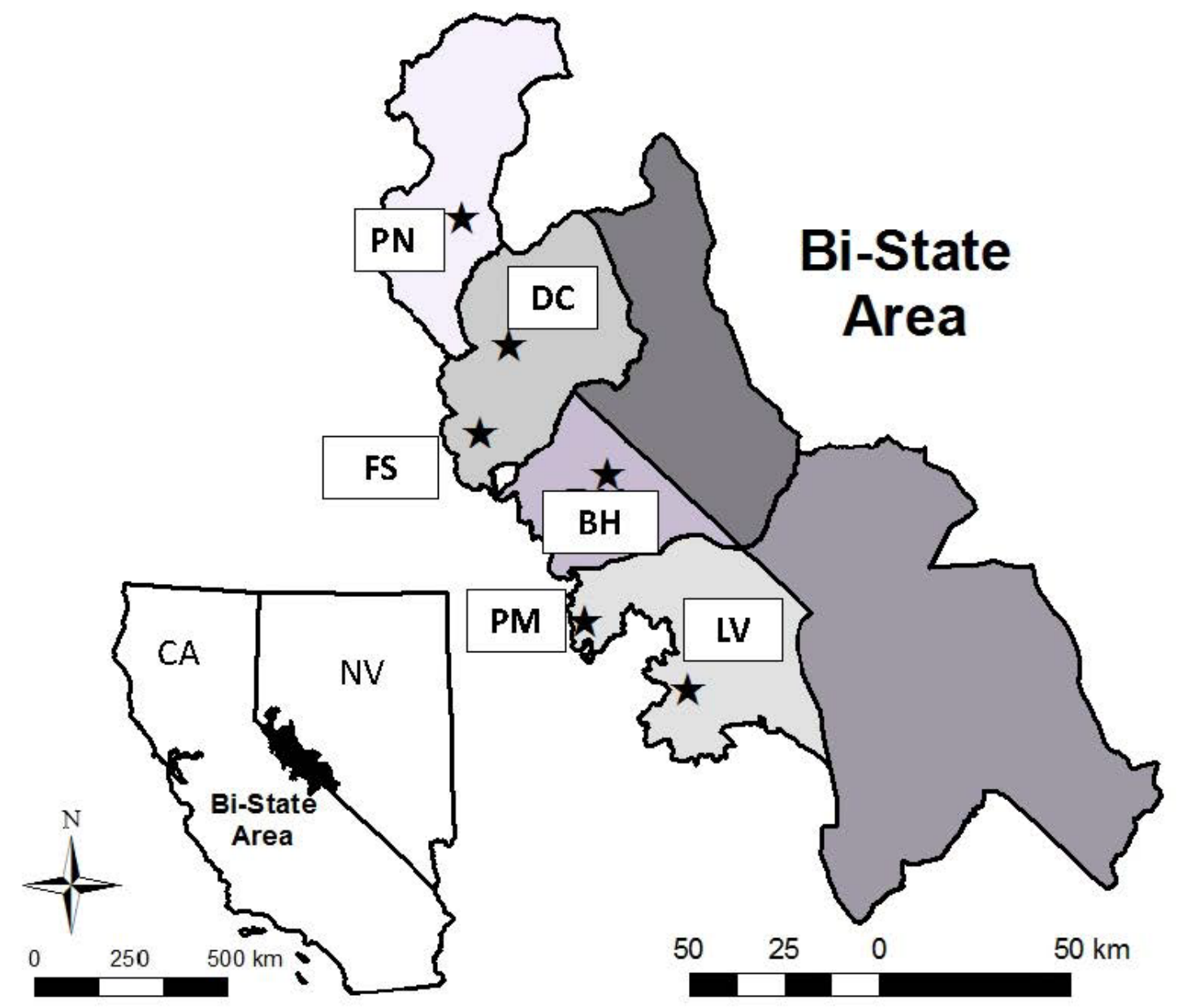

Figure 1. Schematic map showing location of the greater sage-grouse (Centrocercus urophasianus) Bi-State Distinct Population Segment (DPS) study area, California and Nevada. Data from six distinct subpopulations were used to develop integrated population models for the Bi-State DPS. Subpopulations were labeled as PN, Pine Nut; DC, Desert Creek; FS, Fales; BH, Bodie Hills; PM, Parker Meadows; and LV, Long Valley. Dark lines in larger, more detailed schematic map represent boundaries of Population Management Units. 


\section{Methods}

\section{Lek Surveys}

Lek survey protocol generally followed published methodologies (Connelly and others, 2003) and were performed collaboratively by a team of interagency personnel from CDFW, NDOW, Bureau of Land Management, U.S. Forest Service, University of Nevada Reno, University of Idaho, Los Angeles Department of Water and Power, and the USGS. The Bi-State DPS surveys employ a "saturation count" method for deriving the maximum count for a single day. Saturation counts required that all known active leks be counted simultaneously by experienced observers. Male sage-grouse were counted at each lek at least three times in the spring (March-May) to estimate maximum count. The three counts were typically spaced equally in time and overlapped with peak lek attendance by males. Lek counts were conducted between 30 minutes before sunrise and 90 minutes after sunrise. Binoculars, a spotting scope, or both were used to count sage-grouse from a suitable viewing location that afforded a view of the entire lek. A total of three counts per survey were conducted at 10-minute intervals, and the highest count was selected for each survey. The lek count for the peak lek attendance day was obtained for each season.

\section{Sage-Grouse Telemetry Monitoring}

Over the 10-year period, field technicians conducted intensive on-the-ground monitoring of sage-grouse movement, survivorship, and reproduction following release of radio-marked birds. Field data-collection protocols were consistent across the 10-year period. In some situations of differing datacollection procedures, we employed statistical techniques that provided adjustment to the derived demographic parameter estimation (e.g., adjustment for unequal periods to estimate chick survival; see Chick Survival section).

Sage-grouse were captured in close proximity to leks in the spring (March-April) and at various concentration areas in the autumn (October-December) during 2002-12 using spotlighting techniques at night (Giesen and others, 1982; Wakkinen and others, 1992). Sage-grouse captured in 2002 were marked for monitoring in 2003 and subsequent years. Captured sage-grouse were outfitted with necklace-style VHF radio-transmitters (Kolada and others, 2009). During 2012, a subsample of sagegrouse were outfitted with Global Positioning Systems (GPS), Platform Transmitter Terminals (PTTs; North Star Science and Technology, LLC, King George, Virginia), and VHF transmitters (combined weight was $<3$ percent of body mass). The purpose of the GPS transmitter was to collect locations remotely and to transmit (using PTT) to a central database by satellites. The VHF-marked sage-grouse were relocated using hand-held radio receivers and antennae at least twice per week during spring and summer, and at least once per month during winter. Each grouse was circled at a radius of 30-50 m using the loudest signal method to help minimize location error. We approximated the distance and recorded the azimuth from the observer's location (recorded using GPS) to estimate the location coordinates (Universal Transverse Mercator) of the grouse. 
Radio-marked sage-grouse were divided into two age categories for monitoring: (1) sage-grouse that entered their first breeding year but were less than 2 years old were classified as yearlings; and (2) sage-grouse that entered their second breeding year were classified as adults. Deaths within both age categories were documented. Transmitters were equipped with mortality signals and immediately retrieved following sage-grouse fatality. Date of fatality was recorded and corresponded to band identifications. Aerial telemetry was conducted periodically, especially during times when sage-grouse were thought to be missing. Ground locations generally were determined following flights. Data recorded in the field consisted of date of transmitter placement, last date observed alive, date of observed fatality, and date censored from analysis.

Female sage-grouse were located every 3 days during the nesting season (March-June) to estimate the nest initiation date. When a nest was located, subsequent nest checks were conducted every 2-3 days until nest fate was determined. Nest fate was categorized as either successful ( $\geq 1$ egg hatched) or unsuccessful (depredated or abandoned). Data recorded in the field consisted of: (1) date each nest was found; (2) date each nest was last checked alive; (3) date of nest fate determined; and (4) fate of each nest. Clutch sizes were measured opportunistically throughout the incubation period (for example, during incidental flushing or incubation recesses). Clutch sizes also were measured following hatch or depredation by counting egg shells, egg shell membranes, or both. Field technicians noted unreliable clutch size counts and such counts were omitted from analyses. Eggs that failed to hatch and exceeded 30 days of incubation were inspected for fertility and recorded.

Following hatch of nests, broods were monitored intensively. Initial brood sizes were estimated by counting hatched egg shells. Brood-rearing sage-grouse were relocated every 2-3 days with periodic checks of chicks. A final brood count was conducted after a fixed period of time, which differed across years (2003-05, 50 days; 2007-09, 35 days; 2010-11, 28 days; 2012, 50 days). During final brood counts, female sage-grouse were flushed and intensive searches were conducted to count chicks. If no chicks were detected, a second brood check was conducted within 48 hours to confirm brood failure.

\section{Data Compilation}

We obtained and compiled all lek data from databases and data forms that were known to us. We assured that protocols for counting males at lek sites were similar across all years of study and subpopulations. Leks with a recorded integer value of zero or greater for male attendance were included in the analysis. Leks with a blank value were not included (i.e., not surveyed, hence attendance was unknown). Survey data were derived from $>1,500$ independent lek survey observations. From these observations, we derived a total of 429 lek counts that reflected annual maximum male attendance for each lek. We then averaged the maximum lek counts across the subpopulation by year and used these values as data inputs to state-space models. The purpose of averaging was because most subpopulations consisted of more than one lek and we sought to prevent biased low estimates for years of missing data for any given lek.

A total of 358 sage-grouse were marked with VHF transmitters during this 10 -year period. Protocols used in monitoring individually marked sage-grouse were similar across all years. We determined a set of decision rules that excluded data from the analysis during a quality assessment process. Because we conducted a female-based demographic analysis, we first excluded marked male sage-grouse from the data set, as well as female sage-grouse that were not relocated following marking. We then excluded data under specific criteria, which were: (1) relocation dates that were needed to derive demographic parameters were missing; (2) information regarding the status of nest, brood, or sage-grouse were not recorded (e.g., sage-grouse fatality or alive); 3) unique identification of sagegrouse could not be determined; and (4) study site of sage-grouse could not be determined. Following 
this quality control and assessment, we determined that telemetry and survey data were of adequate quality to conduct a female- and stage-based population modeling analysis over a 10-year period (20032012). The sizes of specific sample sets used to derive parameters for population vital rates are reported in the description of each analysis below.

\section{Integrated Population Model}

The framework for the IPM followed published procedures that were described in Kéry and Shaub (2012). The modeling procedures were modified to include comprehensive datasets of life history stages and age classification of sage-grouse populations, as shown in figure 2. Specifically, we modeled male breeding population size $(N)$ as a result of observed male lek counts, as well as annual survival $(S)$ and fecundity $(F)$ of adult and yearling female sage-grouse. Submodels of population vital rates also consisted of stochastic processes, where posterior distributions of population vital rate parameters were derived. From the derived $N$ we calculated the finite rate of population change ( $\lambda$; Caswell, 2001; Gotelli and Ellison, 2004), which took the form:

$$
\lambda_{i j}=\frac{N_{i j+1}}{N_{i j}}
$$

where $i$ represents site, $j$ represents year, and $j+1$ represents a subsequent year. The instantaneous per capita rate of change $(r)$ then was calculated by natural $\log (\ln )$ transformation (Gotelli and Ellison, 2006), and is expressed as:

$$
r_{i j}=\ln \frac{N_{i j+1}}{N_{i j}}
$$

The purpose of calculating $r$ was to appropriately average change in populations across years and sites to make inferences at broader temporal and spatial scales. We performed back calculation to express rate of change as $\lambda$ at broader scales.

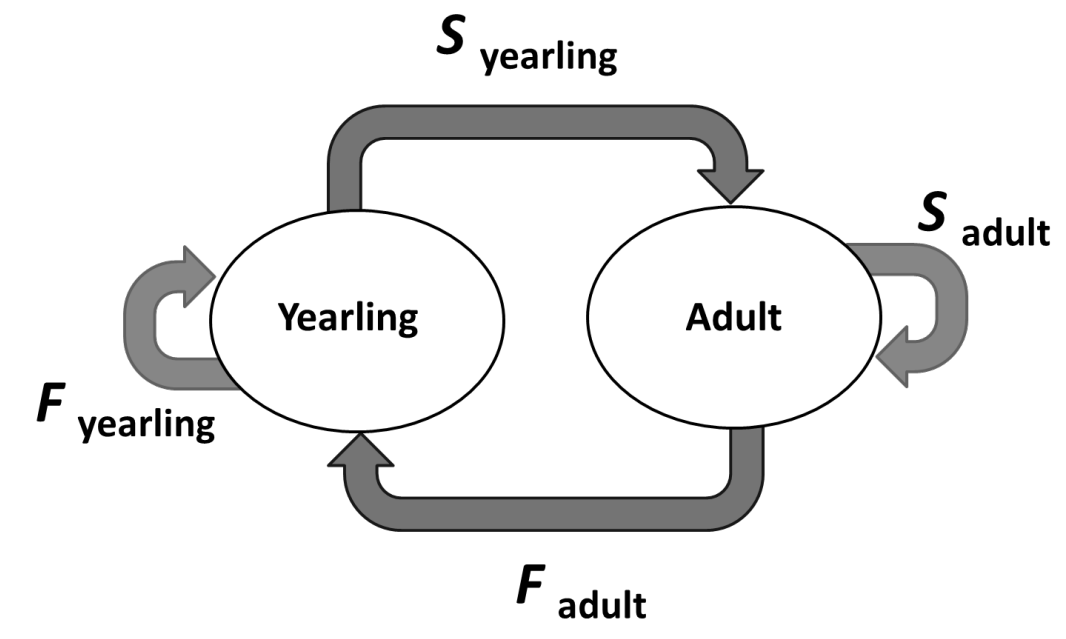

Figure 2. Diagram showing demographic components of the integrated population model for greater sage-grouse in the Bi-State Distinct Population Segment study area, California and Nevada. F, fecundity estimate; S, survival estimate. 


\section{Lek Count Model}

For each year, the number of leks, maximum number of males per lek, number of active leks, and percentage of active leks were compiled by subpopulation combination (table 1). Averaged maximum counts were compiled per year for each subpopulation and entered into a state-space model (Kéry and Shaub, 2012), which is a hierarchical model that decomposed the observed time series of lek counts into process variation and observation error. This model is appropriate for Markovian processes of time-series data where observations are imperfect. Observations $\left(y_{o b s}\right)$ were linked with breeding male population size $N$ at site $i$ and year $j$ using the equation:

$$
\begin{gathered}
y_{o b s, i j}=N_{i j}+\varepsilon_{i j} \\
\varepsilon_{i j} \sim \operatorname{Normal}\left(0, \sigma_{y}^{2}\right)
\end{gathered}
$$

where $\varepsilon$ represents the magnitude of a normally distributed error with mean zero and variance $\sigma_{y}^{2}$. We assumed that the probability of over counting males was similar to the probability of undercounting males and independent of the number of observed males. For sage-grouse counts, this normal distribution most appropriately represents error in observations because sage-grouse can be undercounted and over counted during observations. Undercounting can take place when grouse are difficult to observe and over counting is possible when grouse move around during the counting process. Initial breeding population size for each site was drawn from a discrete uniform $(0,1,000)$ distribution. Average number of males per lek at each site was used as a count index for the state-space model.

Table 1. Summary of lek survey data averaged across years for greater sage-grouse (Centrocercus urophasianus) in the Bi-State Distinct Population Segment study area, California and Nevada, 2003-12.

[Number pairs in parentheses are lower and upper limits of 95-percent confidence interval]

\begin{tabular}{lcrrrrrrr}
\hline \multicolumn{1}{c}{ Subpopulation } & \multicolumn{2}{c}{$\begin{array}{c}\text { Average number } \\
\text { of leks }\end{array}$} & \multicolumn{2}{c}{$\begin{array}{c}\text { Average number of } \\
\text { males per lek }\end{array}$} & $\begin{array}{c}\text { Average number } \\
\text { of active leks }\end{array}$ & \multicolumn{2}{c}{$\begin{array}{c}\text { Percentage of } \\
\text { active leks }\end{array}$} \\
\hline Pine Nut & 2.9 & $(1.3,4.5)$ & 12.0 & $(8.0,15.9)$ & 2.2 & $(1.1,3.3)$ & 88.1 & $(71.8,104.3)$ \\
Desert Creek & 6.2 & $(4.8,7.6)$ & 18.0 & $(13.7,22.3)$ & 5.1 & $(4.0,6.2)$ & 85.1 & $(74.4,95.8)$ \\
Fales & 3.5 & $(2.9,4.1)$ & 9.2 & $(7.7,10.7)$ & 2.5 & $(2.1,2.9)$ & 74.3 & $(62.1,86.5)$ \\
Bodie Hills & 11.2 & $(10.4,12.0)$ & 21.2 & $(15.4,27.0)$ & 9.1 & $(8.3,9.9)$ & 81.7 & $(74.8,88.7)$ \\
Parker Meadows & 3.0 & $(3.0,3.0)$ & 4.7 & $(2.9,6.4)$ & 1.6 & $(1.3,1.9)$ & 53.3 & $(42.6,64.0)$ \\
Long Valley & 8.8 & $(8.0,9.6)$ & 35.6 & $(30.4,40.7)$ & 7.3 & $(6.6,8)$ & 83.3 & $(77.4,89.3)$ \\
\hline
\end{tabular}


Yearling and Adult Survival Model

Using telemetry data, we located individual monitored sage-grouse $(n=248)$ and modeled survival as a continuous process observed at discrete monthly intervals. Encounter histories for survival of yearlings and adults were developed for each sage-grouse. Thus, each month individual sage-grouse were scored as alive or dead. We right censored individuals from the data, meaning we did not always observe the date of death and only had knowledge that individuals survived beyond a certain point. We considered censoring to be a random process, in that sage-grouse were censored under multiple circumstances, including: (1) the study period ended before death was determined; (2) the transmitter failed; or (3) sage-grouse was lost to follow-up monitoring. Thus, all individuals either died or were eventually right censored. We also allowed for graduation of yearling sage-grouse to adults within years. Inference was based on a constant hazards model, meaning the probability of mortality did not change across months. The unit hazard $(U H)$ was modeled where each encounter interval represented a Bernoulli process per month. Modeling procedures for survival followed those described in Halstead and others (2013). The model was expressed as:

$$
\begin{gathered}
U H_{h k i j}=\exp \left(\alpha_{i}+\beta * x_{h i k}+\gamma_{j}\right) \\
\alpha_{i} \sim \operatorname{Normal}\left(\theta, \sigma_{\alpha}^{2}\right) \\
\gamma_{j} \sim \operatorname{Normal}\left(0, \sigma_{\gamma}^{2}\right)
\end{gathered}
$$

where $U H$ was a function of random effect for site $\alpha_{j}$, a random effect for year $\gamma_{i}$, both of which were assumed to arise from Normal distributions with mean $\theta$ and zero, respectively, and variances $\sigma_{\alpha}^{2}$ and $\sigma_{\gamma}^{2}$, respectively, and expected change in the $\ln$ (hazard ratio) of magnitude $\beta$, where the indicator of age was equal to one for adults. The hazard ratio represented the ratio of hazard rates (in this case, monthly risk of morality) between the two age classes. Subscripts $h, k, i$, and $j$ reference grouse, month, site, and year. Following the modeling process, we derived the annual survival parameter $\left(S_{a n}\right)$ as:

$$
\begin{gathered}
S_{a n, i j}=e^{-C H_{i j}} \\
C H_{i j}=\sum_{j=1}^{T=12} U H_{k i}
\end{gathered}
$$

where $\mathrm{CH}$ represented the cumulative hazard ( $\mathrm{T}=12$ months represented annual survival). We also attempted to fit a first-order autoregressive hazard model; adding this complexity caused very slow mixing with no convergence to a stationary distribution. 


\section{Fecundity Model}

Methods of collecting reproductive data across all sites and years were relatively consistent. Fecundity was decomposed into several submodels - specifically, nest propensity ( $n p$ ), nest survival $(n s)$, clutch size $(c)$, egg hatchability $(h)$, chick survival $(c s)$, juvenile survival $(j s)$. To derive fecundity parameters, a female-based, age classified population projection model was used. The life history stage parameters were estimated for (1) first nests, and (2) second nests. No third nest attempts were recorded. Thus, the equation for fecundity $(F)$ took the form:

$$
\begin{gathered}
F_{i j a}=\left(n p 1_{a} \times c 1_{i j a} \times n s 1_{i j a} \times h_{a} \times c s_{i j a} \times j s_{a}\right)+ \\
\left(\left(1-n s 1_{i j a}\right) \times n p 2_{i j a} \times c 2_{i j a} \times n s 2_{i j a} \times h_{a} \times c s_{i j a} \times j s_{a}\right)
\end{gathered}
$$

where $F$ was estimated for each site $i$, year $j$, and age class $a$ combination. $F$ was divided by 2 because this model is female-based and an even sex ratio as reported in Atamian and Sedinger (2010) was assumed. We derived posterior distributions of parameters for each of the components of $F$ using separate models.

We accounted for the hierarchical structure of the data (spatial and temporal) by fitting random intercept effect structures for site and year (Zuur and others, 2009). We also incorporated female age as a fixed effect. These effects were fit as additive and nested structures (i.e., random site was nested within year; Zuur and others, 2009). Final $\lambda$ values were similar under both scenarios. However, the derived demographic parameters (i.e., $S$ and $F$ as a function of $n p, c$, and $n s$ ) often differed for individual population vital rates. The additive random effect structure is more robust in cases where data are sparse (missing site and year combinations). This structure allows other site and year data to help inform those combinations of missing data and provides more stable estimates with narrower credible intervals. Findings in this analysis are a result of the additive random effect structure because this structure demonstrated better model stability and was more appropriate for the sampling within the BiState DPS.

Nest propensity parameters for first nests $(n p 1)$ were not derived directly from data collected in the Bi-State DPS during this study period. The reliability of these data is questionable largely because of a relatively high probability of missing the first nest attempt while tracking sage-grouse. However, an extensive study conducted by Taylor and others (2012) provided information across numerous sagegrouse studies range-wide and reported 0.96 (95-percent confidence interval $[\mathrm{CI}]=0.94-0.97$ ) and 0.89 (95-percent $\mathrm{CI}=0.87-0.91$ ) for adults and yearlings. These values were considered reliable because of the large number of studies used in the analysis. However, we provided priors that were slightly wider than these published confidence intervals as a more conservative approach. We set informative priors for adults $=\operatorname{Beta}(97,5)$ and yearlings $=\operatorname{Beta}(90,12)$. In the absence of additional information, we assumed this proportion to be constant among sites and years. 
Parameters were derived for the propensity to nest a second time ( $n p 2)$ directly from data collected in the Bi-State DPS. Data to estimate second nest propensity were more reliable than those for the first nests because females were monitored intensively (relocated every 1-3 days) following first nest failures $\left(n_{\text {failed nests }}=44\right)$. Field technicians were able to determine whether or not a female attempted a second nest by approaching sage-grouse and confirming nesting when sage-grouse were located at the same coordinate as the previous location. Second-nest propensity data were modeled as arising from a Binomial distribution as follows:

$$
\begin{gathered}
y_{n p 2, i j} \sim \operatorname{Binomial}\left(p_{n p 2, i j}, n_{n p 2, i j}\right) \\
\operatorname{logit}\left(p_{n p 2, i j}\right)=a_{i}+\beta * x_{i j}+\gamma_{j} \\
\alpha_{i} \sim \operatorname{Normal}\left(\theta, \sigma_{\alpha}^{2}\right) \\
\gamma_{j} \sim \operatorname{Normal}\left(0, \sigma_{\gamma}^{2}\right)
\end{gathered}
$$

where the number of unsuccessful nests at each site in each year were denoted by $n_{n p 2, i j}$. In this model, $y_{n p 2, i j}$ represents the number of renests and $\operatorname{logit}\left(p_{n p 2, i j}\right)$ is a linear function of random site effects $\alpha_{i}$, random year effects $\gamma_{j}$, both of which were assumed to arise from Normal distributions with mean $\theta$ and zero, respectively, and variances $\sigma_{\alpha}^{2}$ and $\sigma_{\gamma}^{2}$, respectively, and a change in the expected count of magnitude $\beta$, where the indicator of age was equal to one for adults.

Data for clutch size of first nests $\left(\mathrm{c} 1 ; n_{\text {clutches }}=190\right)$ were modeled as arising from the Poisson distribution as follows:

$$
\begin{gathered}
y_{c 1, c i j} \sim \operatorname{Poisson}\left(\mu_{c 1, c i j}\right) \\
\log \left(\mu_{c 1, c i j}\right)=a_{i}+\beta * x_{c i j}+\gamma_{j} \\
\alpha_{i} \sim \operatorname{Normal}\left(\theta, \sigma_{\alpha}^{2}\right) \\
\gamma_{j} \sim \operatorname{Normal}\left(0, \sigma_{\gamma}^{2}\right)
\end{gathered}
$$

Thus, the $\log$ expected count of clutch size $\mu_{c 1}$ at clutch $c$, site $i$, and year $j$ is a linear function of random site effects $\alpha_{i}$, random year effects $\gamma_{j}$, both of which were assumed to arise from Normal distributions with mean $\theta$ and zero, respectively, and variances $\sigma_{\alpha}^{2}$ and $\sigma_{\gamma}^{2}$, respectively, and a change in the expected count of magnitude $\beta$ if the indicator of age is equal to 1 . Parameter estimates for clutch sizes of second nests (c2) were derived in a separate modeling process that followed the same procedures. 
Survival parameters of first $(n s 1)$ and second nests $(n s 2)$ were derived separately. Nest survival ( $n_{\text {nests }}=251$ ) was modeled as proportional hazards as expressed in equation 4. However, for nest survival estimation, encounter histories were developed for each nest and modeled as a continuous process at discrete daily intervals. In this case, $\mathrm{T}=38$ was used to estimate survival during 10 days of laying and 28 days of incubation. Female age was used as a fixed effect in this model, which also included random effects for site and year.

Data on egg hatchability ( $\left.h ; n_{\text {hatchability }}=111\right)$ in the Bi-State DPS were derived for most nests that were successful. Hatchability was modeled as arising from a Binomial distribution (logit-link function) following equation 7 , where the indexing differs as:

$$
\begin{gathered}
y_{h, e i j} \sim \operatorname{Binomial}\left(p_{h, e i j}, n_{h, e i j}\right) \\
\operatorname{logit}\left(p_{h, e i j}\right)=a_{i}+\beta * x_{e i j}+\gamma_{j} \\
\alpha_{i} \sim \operatorname{Normal}\left(\theta, \sigma_{\alpha}^{2}\right) \\
\gamma_{j} \sim \operatorname{Normal}\left(0, \sigma_{\gamma}^{2}\right)
\end{gathered}
$$

where the initial number of eggs laid in a clutch $e$ represented the number of trials $\left(n_{h, e i j}\right)$ at site $i$ and year $j$, and the number of hatched eggs represented successes $\left(y_{h, i j j}\right)$. The $\operatorname{logit}\left(p_{h, e i j}\right)$ is a linear function of random site effects $\alpha_{i}$, random year effects $\gamma_{j}$, both of which were assumed to arise from Normal distributions with mean $\theta$ and zero, respectively, and variances $\sigma_{\alpha}^{2}$ and $\sigma_{\gamma}^{2}$, respectively, and a change in the expected count of magnitude $\beta$, where the indicator of age was equal to one for adults..

As described previously, chicks were not directly marked and followed using radio-telemetry to reduce researcher disturbance. Thus, chick survival $(c s)$ probabilities were derived from the two brood counts $\left(n_{\text {broods }}=120\right)$ with time interval lengths that varied across the 10-year study period. However, the number of days elapsed from nest hatch to brood count varied by study year (2003-05, 50 days; 200709, 35 days; 2010-11, 28 days; 2012, 50 days). Therefore, we employed an adjustment in estimating survival probabilities depending on the year of study. We modeled chick survival based on brood count data as arising from a Binomial distribution where the initial brood size was scored as the number of trials and chicks that survived to days $d$ were scored as successes and took the form:

$$
y_{c s, b i j} \sim \operatorname{Binomial}\left(p_{c s, b i j d}, n_{c s, b i j}\right)
$$

where $d$ on the binomial probability $p$ is $d=d(j)$ and represents one of three survival periods depending on the year $j$ of data collection ( $d=28,35$, or 50 ). For a 35 -day interval, the probability of survival is modeled by this logistic relationship: 


$$
\begin{gathered}
\operatorname{logit}\left(p_{c s, b i j, 35}\right)=a_{i}+\beta * x_{b i j}+\gamma_{j} \\
\alpha_{i} \sim \operatorname{Normal}\left(\theta, \sigma_{\alpha}^{2}\right) \\
\gamma_{j} \sim \operatorname{Normal}\left(0, \sigma_{\gamma}^{2}\right)
\end{gathered}
$$

In this model, $y_{c s, b i, j}$ represents the number of chicks that survived for each brood $b$ at site $i$ year $j$. The $\operatorname{logit}\left(p_{c s, b i j, 35)}\right)$ is a linear function of random site effects $\alpha_{j}$, random year effects $\gamma_{i}$, and a change in the expected count of magnitude $\beta$, where the indicator of age was equal to one for adults. We assumed a constant hazard function, and consistent with this assumption the probabilities of survival for the other intervals are related as follows:

$$
p_{c s, b i j d}=\left\{\begin{array}{cl}
\left(p_{c s, b i j, 35}\right)^{28 / 35}, & t=28 \\
p_{c s, b i j, 35}, & t=35 \\
\left(p_{c s, b i j, 35}\right)^{50 / 35}, & t=50
\end{array}\right.
$$

Juvenile sage-grouse (post-fledging, $>35$ days and $<1$ year old) were not radio-marked and tracked in the Bi-State DPS. However, we derived a posterior distribution of juvenile survival rates $(j s)$ during this period by using an informative prior of 0.75 ( 95 -percent $\mathrm{CI}=0.67-0.82$ ) reported in Taylor and others (2012) in the form of $\operatorname{Beta}(100,34)$.

\section{Joint Likelihood}

In a final step of the IPM, we followed procedures described in Kéry and Shaub (2012) and formulated a joint likelihood which represents the component likelihoods of population count data (state-space model described in equation 3), yearling and adult survival data (proportional hazards model described in equation 4), and fecundity data (submodel components described in equation 6). The subcomponents of the IPM used in deriving posterior distributions for the breeding population indices $(N)$ are shown in figure 3 . We then calculated population growth rate across spatial and temporal scales using equations 1 and 2. For each subpopulation, we calculated the probability that the subpopulation was increasing, stable, and decreasing based on the posterior distributions of derived parameters. We then calculated the odds of increase from the probability values, where the odds of increase represented the probability of increase divided by the sum of the probability of decrease and stability. Likewise, we calculated the odds of decrease. We then created a ratio of the two odds (increase:decrease) and applied natural logarithmic transformation to that ratio. The purpose of this procedure was to quantify evidence for population trends (when ratio equals 0 , then the odds of increase are the same as decrease). Plots were created for $\mathrm{N}, \lambda$, and $\ln$ (odds ratio). Posterior distributions of parameters were summarized as median and 95 percent credible intervals (CRI) were expressed as 0.025 quantile- 0.975 quantile. Lek count observation data were summarized by mean and 95 percent confidence intervals $(\mathrm{CI})$ as 1.96 multiplied by the standard error. 
We used JAGS 3.3.0 (R version 3.0.0), using the package rjags to obtain posterior samples of parameters. We used Markov chain Monte Carlo methods and ran five independent chains of 100,000, following a burn-in of 100,000. Chains were thinned by a factor of 500 because of storage limitations given the large number of parameters. We found no evidence for lack of convergence, observed by examining history plots.

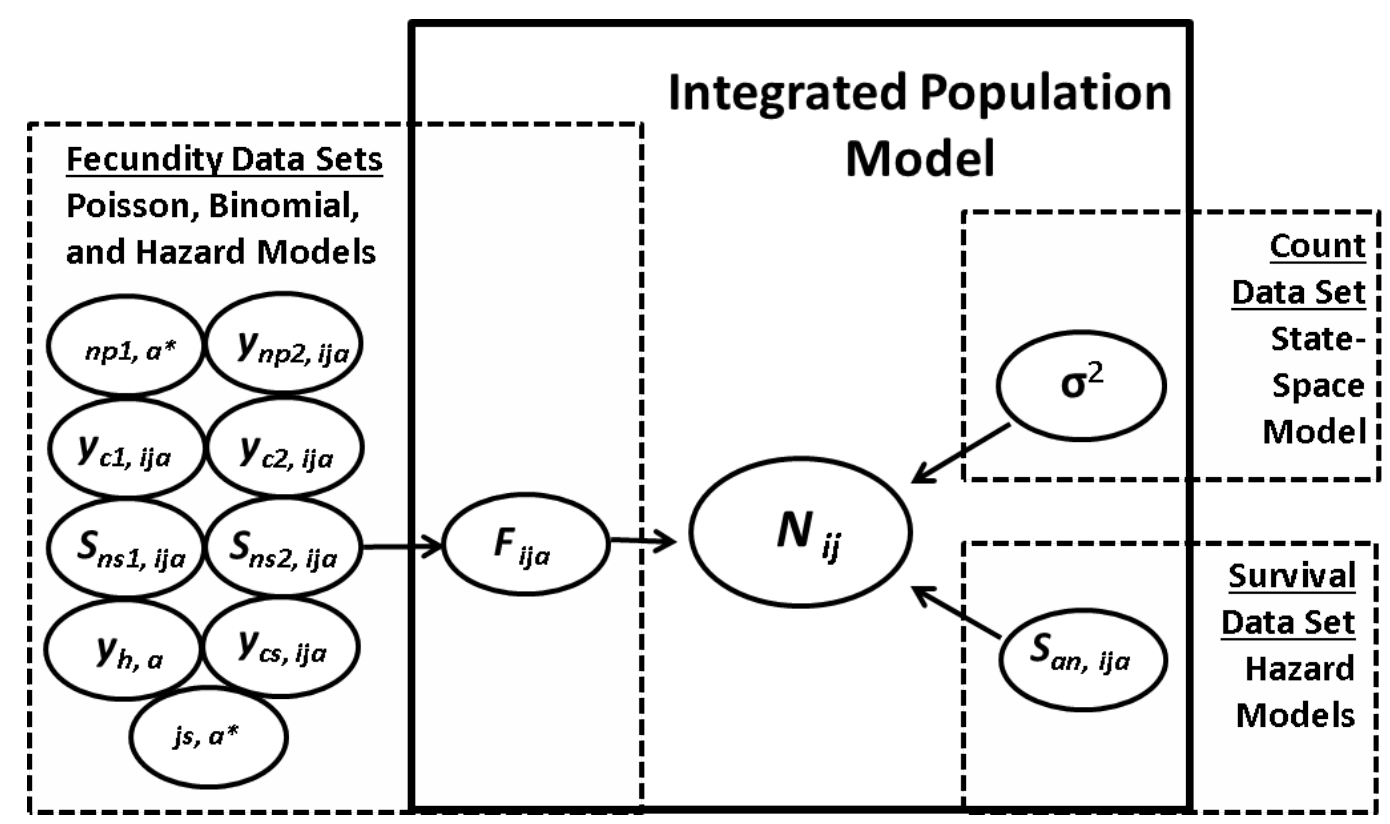

Figure 3. Diagram showing integrated population model [modified from Kéry and Shaub (2012)] for greater sagegrouse in the Bi-State Distinct Population Segment study area, California and Nevada. Ovals represent derived parameters and dashed squares represent submodels. Ovals overlapping more than one square represents parameters informed by multiple data sources; arrows indicate flow of information; np1, propensity of first nest; $y_{n p 2,}$ second nesting propensity; $y_{c 1}$, clutch size from first nest; $y_{c 2}$, clutch size from second nest; $S_{n s 1}$, survival of first nest; $S_{n s 2}$, survival of second nest; $y_{h}$, hatchability; $Y_{c s}$, chick survival; js, juvenile survival; $F$, fecundity; $S_{a n}$, annual survival; $\sigma^{2}$, error of lek observations; $N$, breeding number of sage-grouse; $i$, site; $j$, year; $a$, age class. 


\section{Results and Interpretation}

This document consists of key findings for each subpopulation as well as inferences at the regional scale (Bi-State DPS). These findings represent information regarding population vital rate estimation, observed lek counts, $N$, $\lambda$, and odds ratios for each subpopulation and the Bi-State DPS. Derived parameters were averaged across years and listed by site (appendix A) and averaged across sites and listed by years (appendix B). In the following subsections, general estimates of survival $(S)$ and fecundity $(F)$ for adults $(a)$ and yearlings $(y)$ for each subpopulation were reported, as well as subpopulation vital rate estimates that appear to differ from inferences at the regional scale.

\section{Pine Nut Subpopulation}

The average number of observed males on leks was 12.0 (95-percent $\mathrm{CI}=8.0-15.9$; table 1 ), which was slightly less than $N$ at 12.1 (95-percent $\mathrm{CRI}=7.2-17.6$; fig. 4). The pattern of $N$ across years is similar to that of $N$ averaged across the entire Bi-State DPS (fig. 5). Within the Pine Nut subpopulation, growth rate $(\lambda)$ was 1.04 (95-percent CRI $=0.92-1.51$; fig. 6) and per capita growth $(r)$ was $0.04(95-$ percent $\mathrm{CRI}=-0.08-0.41)$. The fecundity rate for adults $\left(F_{\mathrm{a}}=0.47,95\right.$-percent $\left.\mathrm{CRI}=0.19-1.00\right)$ and yearlings $\left(F_{\mathrm{y}}=0.36,95\right.$-percent $\left.\mathrm{CRI}=0.13-0.93\right)$ in the Pine Nut subpopulation was similar to the rates for other subpopulations. Survival for adults $\left(S_{\mathrm{a}}\right)$ was $0.70(95 \mathrm{CRI}=0.54-0.84)$, and survival for yearlings $\left(S_{\mathrm{y}}\right)$ was $0.70(95$-percent $\mathrm{CRI}=0.53-0.85)$.

\section{Desert Creek Subpopulation}

The average number of observed males on leks was 18.0 (95-percent CRI=13.7-22.3; table 1), which was slightly lower than the $N$ at 18.1 (95-percent CRI=12.8-24.3; fig. 4). Within the Desert Creek subpopulation, $\lambda$ was 1.03 (95-percent $\mathrm{CRI}=0.92-1.41$; fig. 6) and $r$ was 0.03 (95-percent $\mathrm{CRI}=-$ 0.09-0.34). $F_{\mathrm{a}}$ in the Desert Creek subpopulation was highest $(0.53,95$-percent CRI $=0.25-1.16)$, whereas $F_{\mathrm{y}}$ was similar $(0.40,95$-percent $\mathrm{CRI}=0.15-1.13)$ to $F_{\mathrm{y}}$ of other subpopulations. Survival for adults $\left(S_{\mathrm{a}}=0.68 ; 95\right.$-percent $\left.\mathrm{CRI}=0.51-0.81\right)$ and yearlings $\left(S_{\mathrm{y}}=0.68\right.$; 95-percent $\left.\mathrm{CRI}=0.51-0.82\right)$ was similar to survival for other subpopulations.

\section{Fales Subpopulation}

The average number of observed males on leks was 9.2 (95-percent CRI=7.7-10.7; table 1), higher than $N$ at 8.7 (95-percent $\mathrm{CRI}=0.7-14.6$; fig. 4). Within the Fales subpopulation, $\lambda$ was 0.98 (95percent $\mathrm{CRI}=0.84-1.55$; fig. 6). Per capita growth $(r=-0.02,95$-percent $\mathrm{CRI}=-0.18-0.44)$ was the second lowest among all subpopulations. The fecundity rate for Fales $\left(F_{\mathrm{a}}=0.50,95\right.$-percent $\mathrm{CRI}=0.20-1.72$; $F_{\mathrm{y}}=0.49,95$-percent $\left.\mathrm{CRI}=0.16-4.65\right)$ was similar to the rates for other subpopulations. Survival $\left(S_{\mathrm{a}}=0.58,95\right.$-percent CRI $=0.03-0.76 ; S_{\mathrm{y}}=0.57,95$-percent $\left.\mathrm{CRI}=0.04-0.76\right)$ was lower for Fales than for other subpopulations. However, chick survival rates for both adults $\left(c 1_{\mathrm{a}}=0.45,95\right.$-percent $\mathrm{CRI}=0.27-$ $0.69)$ and yearlings $\left(c 1_{y}=0.38,95\right.$-percent $\left.C R I=0.20-0.63\right)$ were higher for Fales than for other subpopulations. 


\section{Bodie Hills Subpopulation}

The average number of observed males on leks was 21.2 (95-percent CRI=15.4-27.0; table 1). $N$ was the second highest of the six subpopulations (21.4; 95-percent CRI=15.5-27.8; fig. 4). Bodie Hills had the highest $\lambda(1.08,95$-percent $\mathrm{CRI}=0.97-1.42)$ and $r(0.08,95$-percent $\mathrm{CRI}=-0.03-0.35)$ among all subpopulations (fig. 6). The fecundity rate for Bodie Hills $\left(F_{\mathrm{a}}=0.49,95\right.$-percent $\mathrm{CRI}=0.25-0.90$; $F_{\mathrm{y}}=0.42,95$-percent $\left.\mathrm{CRI}=0.17-1.17\right)$ was similar to the rates for other subpopulations. Survival of the first nest generally was highest for Bodie Hills $\left(n s 1_{\mathrm{a}}=0.46,95\right.$-percent $\mathrm{CRI}=0.27-0.65 ; n s 1_{\mathrm{y}}=0.48,95$ percent $\mathrm{CRI}=0.27-0.68)$. However, chick survival $\left(c s 1_{\mathrm{a}}=0.38,95\right.$-percent $\mathrm{CRI}=0.23-0.57 ; c s 1_{\mathrm{y}}=0.31$, 95-percent $\mathrm{CRI}=0.17-0.51$ ) was lowest when compared to chick survival in other subpopulations.

\section{Parker Meadows Subpopulation}

The average number of observed males on leks was 4.7 (95-percent CRI=2.9-6.4; table 1 ) and $N$ was 4.5 (95-percent CRI=1.6-8.7; fig. 4). Parker Meadows had the lowest overall $\lambda(0.85,95$-percent $\mathrm{CRI}=0.74-1.29$; fig. 6) and $r(-0.16,95 \mathrm{CRI}=-0.31-0.25)$ compared to other subpopulations (fig. 6). The fecundity rate for Parker Meadows $\left(F_{\mathrm{a}}=0.15,95\right.$-percent $\mathrm{CRI}=0.06-0.39 ; F_{\mathrm{y}}=0.17,95$-percent $\mathrm{CRI}=0.05-0.49)$ was the lowest rate of all subpopulations. Survival $\left(S_{\mathrm{a}}=0.67,95\right.$-percent CRI $=0.47-$ $0.80 ; S_{\mathrm{y}}=0.66,95$-percent $\left.\mathrm{CRI}=0.47-0.81\right)$ was similar to survival for other subpopulations. Egg hatchability for adults $\left(h_{\mathrm{a}}=0.34,95\right.$-percent $\left.\mathrm{CRI}=0.15-0.61\right)$ and yearlings $\left(h_{\mathrm{y}}=0.51,95\right.$-percent $\mathrm{CRI}=0.24-0.78$ ) was substantially lower than $h_{\mathrm{a}}$ and $h_{\mathrm{y}}$ of other subpopulations.

\section{Long Valley Subpopulation}

The average number of observed males on leks was 35.6 (95-percent CRI $=30.4-40.7$; table 1$)$ and $N$ was 35.6 (95-percent $\mathrm{CRI}=28.7-42.8$; fig. 4). Within the Long Valley subpopulation, $\lambda$ was 1.02 (95-percent $\mathrm{CRI}=0.94-1.28$; fig. 6) and $r$ was 0.02 (95-percent $\mathrm{CRI}=-0.06-0.25$ ). The fecundity rate for Long Valley $\left(F_{\mathrm{a}}=0.46,95\right.$-percent $\mathrm{CRI}=0.22-0.92 ; F_{\mathrm{y}}=0.36,95$-percent $\left.\mathrm{CRI}=0.13-0.99\right)$ was similar to the other subpopulations. Survival $\left(S_{\mathrm{a}}=0.68,95\right.$-percent CRI $=0.54-0.80 ; S_{\mathrm{y}}=0.68,95$-percent CRI $=0.52-$ $0.81)$ also was similar to survival for other subpopulations. Nest survival for first nests $\left(n s 1_{\mathrm{a}}=0.37,95\right.$ percent $\mathrm{CRI}=0.18-0.56 ; n s 1_{\mathrm{y}}=0.39,95$-percent $\left.\mathrm{CRI}=0.16-0.60\right)$ was the lowest of all subpopulations. 
A. Pine Nut

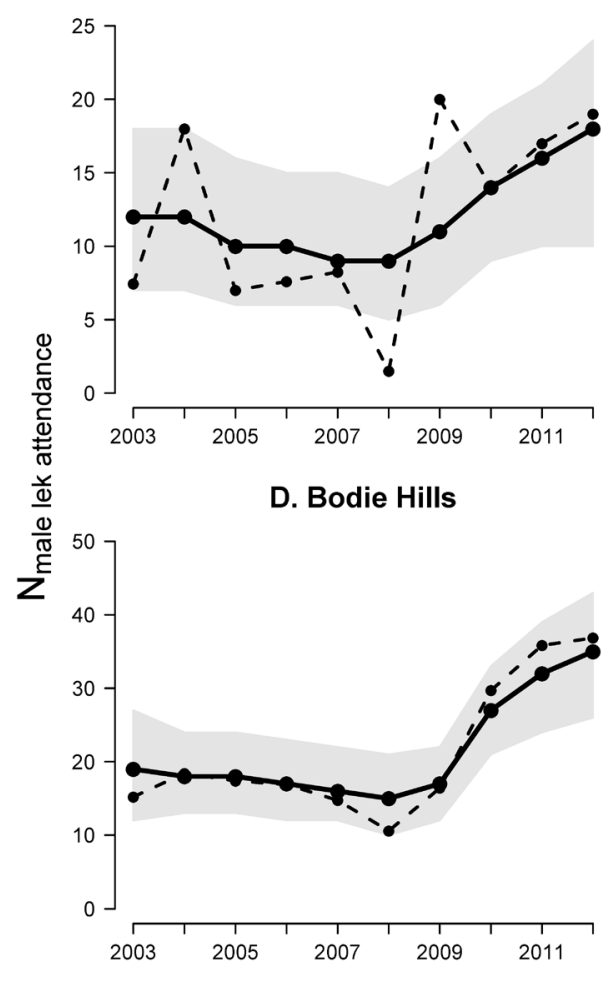

B. Desert Creek
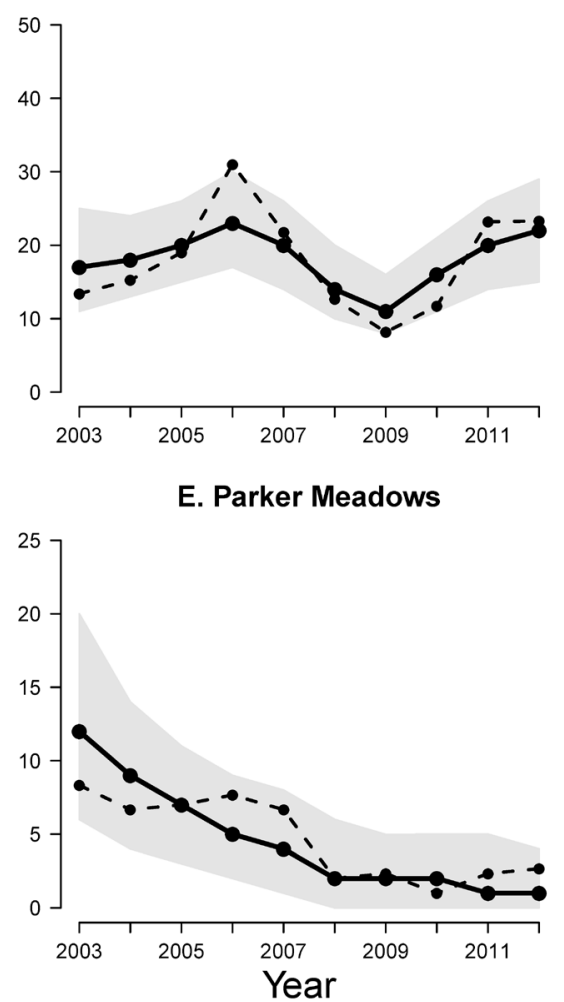

C. Fales
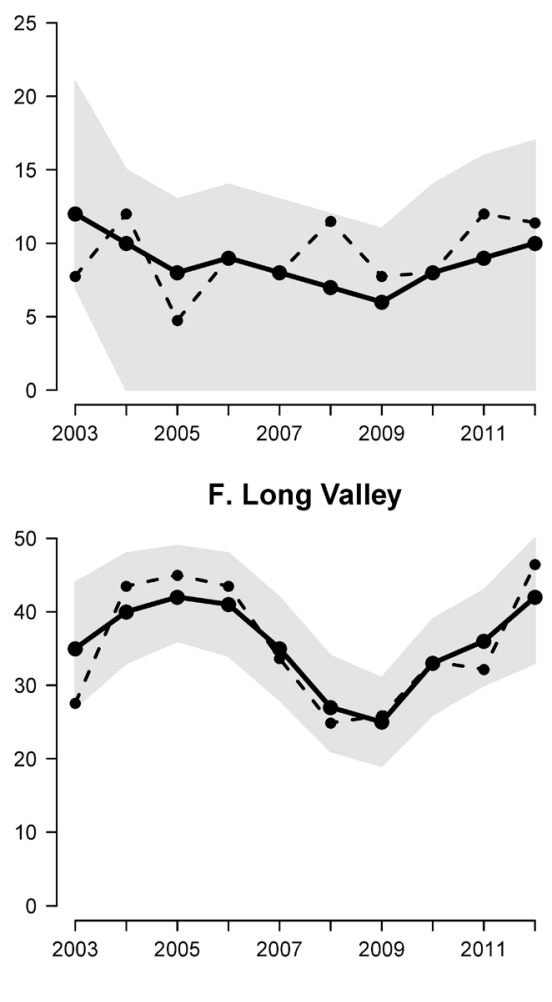

Figure 4. Graphs showing estimated number of male sage-grouse per lek (solid line) and lek observations (dashed line), Bi-State Distinct Population Segment study area, California and Nevada, 2003-12. Gray shading represents the 95-percent credible interval. 


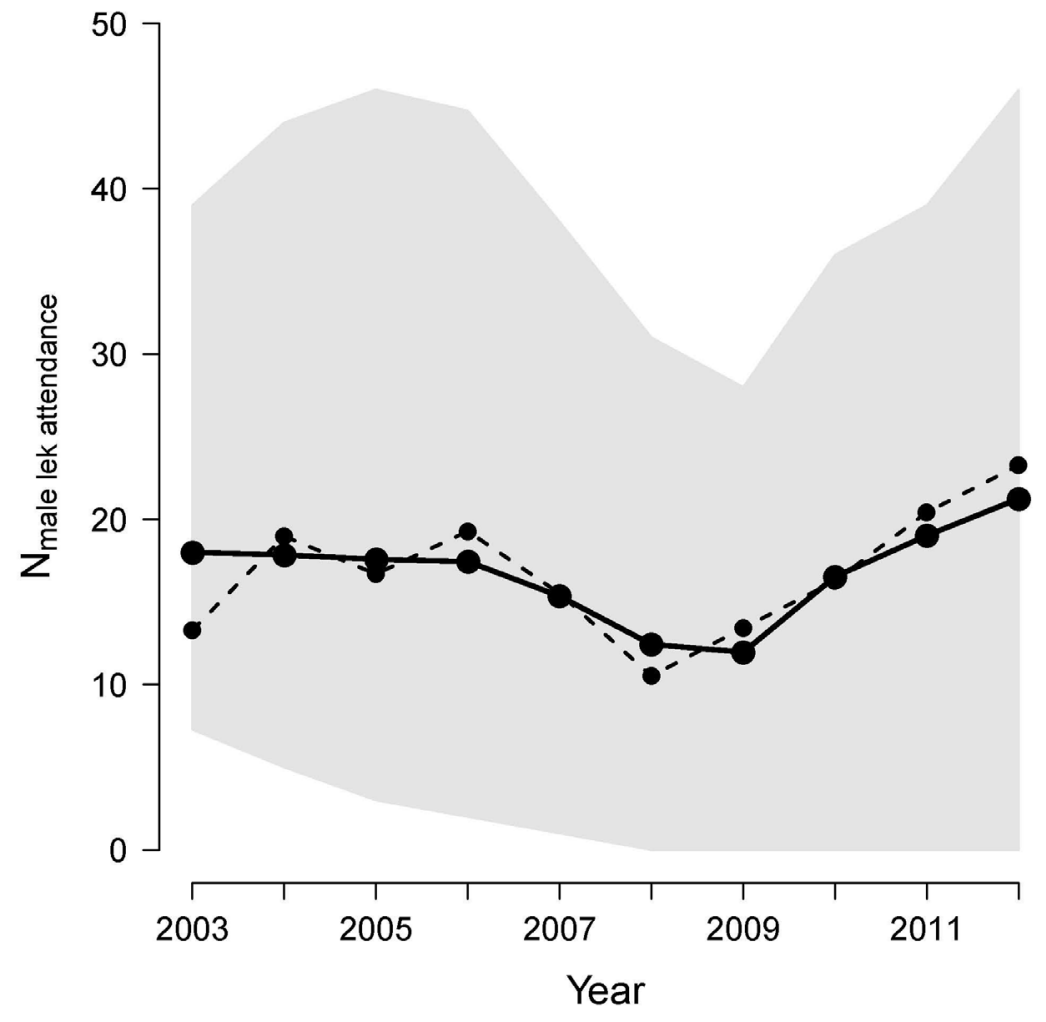

Figure 5. Graphs showing annual lek attendance counts (solid line) and estimates (dashed line) across all Bi-State Distinct Population Segment study area sites, California and Nevada, 2003-12. Gray shading represents the 95-percent credible interval. 


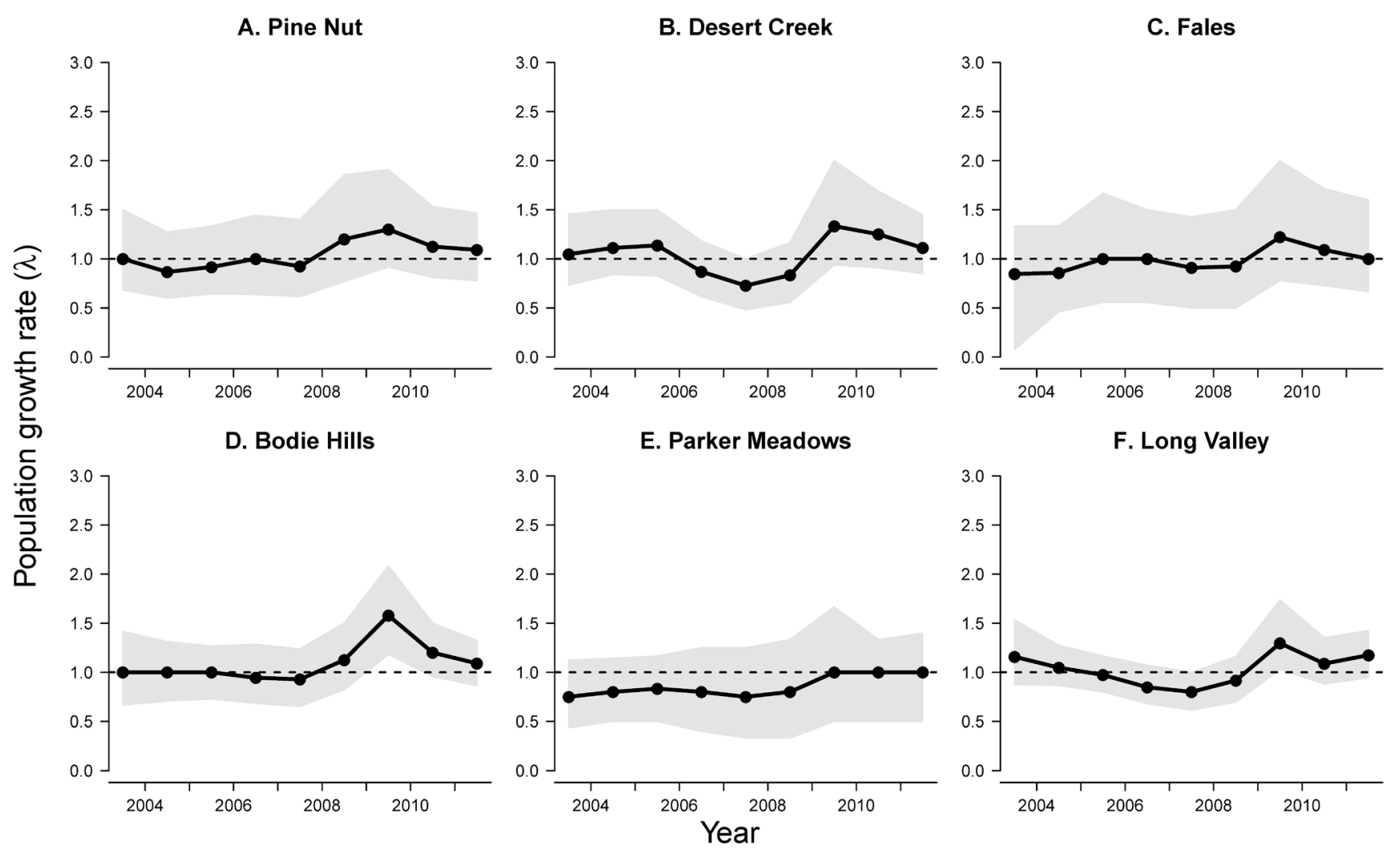

Figure 6. Graphs showing population growth rate $(\lambda)$ for each monitored site $(A-F)$, Distinct Population Segment study area, California and Nevada, 2003-12. Gray shading represents the 95-percent credible interval. The dashed horizontal line represents a stable population. 


\section{Bi-State DPS Summary and Synthesis}

The preponderance of evidence suggests that sage-grouse populations are stable ( $\lambda$ was 1.00 ; 95 percent CRI=0.88-1.41) within Bi-State DPS in its entirety over the period of 2003-2012 (fig. 7; population vital rate parameters are reported in table 2). Based on the posterior distribution of $\lambda$ across the Bi-State DPS, the following probabilities were calculated for the period 2003-2012: (1) increased population, 42.5 percent; (2) stable population, 15.8 percent; and (3) decreased population, 41.6 percent. The odds of increase to decrease is 1.03 , meaning that the odds that the trend in the population is increasing was 3 percent greater than odds of it decreasing (fig. 9). However, substantial variation was detected in $\lambda$ across years and sites as reported above. For example, data suggest that the odds that the Parker Meadows subpopulation is decreasing was 17.4 times greater than the odds that this subpopulation is increasing. Based on these findings, this subpopulation appears to be the only one with compelling evidence within the Bi-State that is currently at risk of extinction. The derived parameters for hatchability at Parker Meadows (median; $h_{\mathrm{y}}, 0.51 ; h_{\mathrm{a}}, 0.34$; appendix B) were approximately half of those values that were derived across the Bi-State overall (0.5 quantile; $h_{\mathrm{y}}, 0.89 ; h_{\mathrm{a}}, 0.83$; table 2$)$. Field observations concluded that decreased hatchability was a result of low egg fertility rates. Recent evidence indicate that the Parker Meadows subpopulation contains substantially lower mitochondrial and nuclear genetic variation than other subpopulations within the Bi-State DPS (Oyler-McCance and others, in press), which may be concerning because this subpopulation is isolated and small. Parker Meadows may benefit from a translocation program aimed at augmenting greater sage-grouse (OylerMcCance and others, in press). Nevertheless, these data indicate that the Bi-State DPS in its entirety is stable, despite the strong evidence of a declining trend in the Parker Meadows subpopulation. In other words, the Parker Meadows subpopulation, which consisted of two leks with less than 5 males on average (table 1), had relatively low influence on the overall population trend averaged across the entire DPS (fig. 7). 


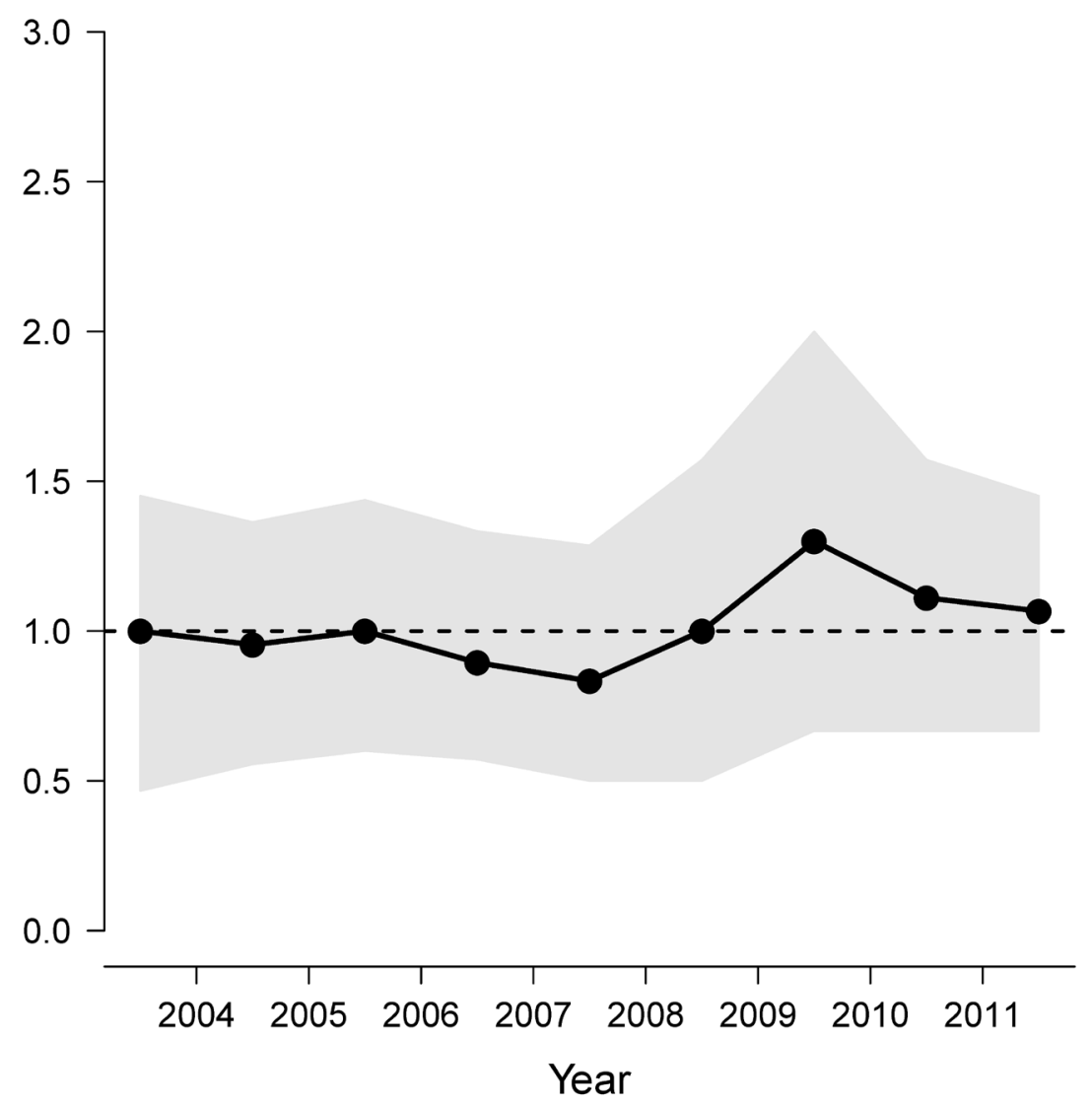

Figure 7. Graph showing annual population growth rate $(\lambda)$ across all Bi-State Distinct Population Segment study area sites, California and Nevada, 2003-12. Gray shading represents the 95-percent credible interval. The dashed horizontal line represents a stable population. 
A. Pine Nut

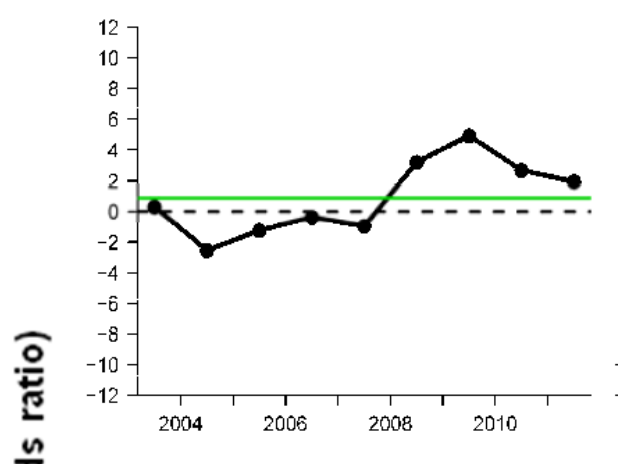

D. Bodie Hiilis

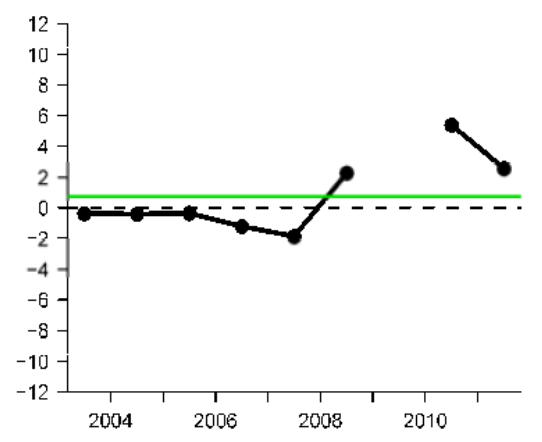

B. Desert Creek

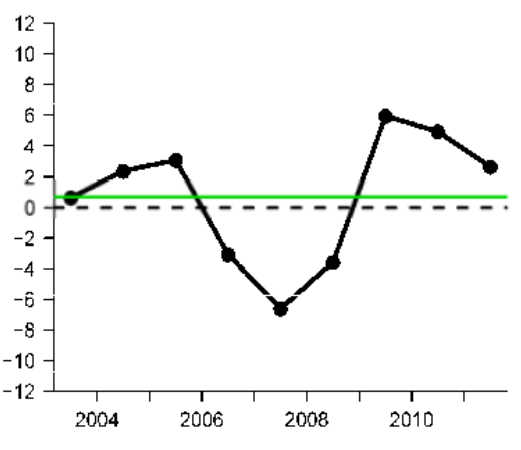

E. Parker Meadows

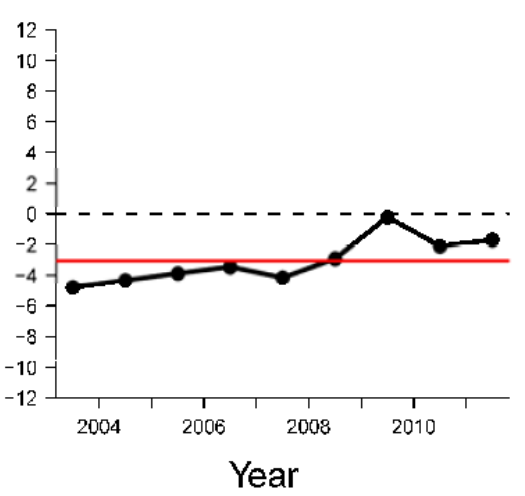

C. Fales

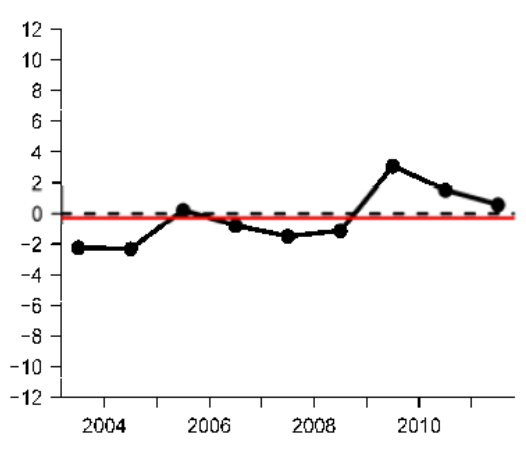

F. Long Vailey

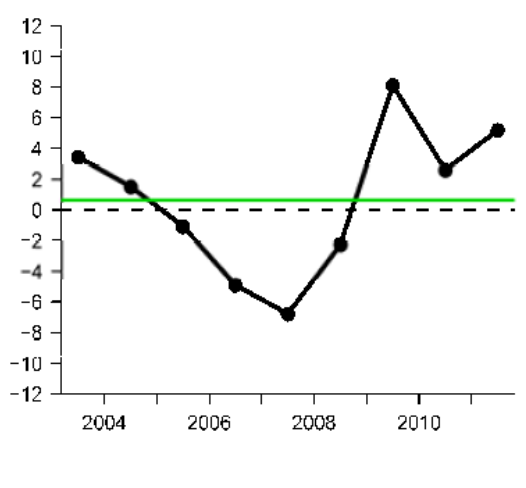

Figure 8. Graphs showing In(odds ratio) of population increase to decrease for each monitored site (A-F), Bi-State Distinct Population Segment study area, California and Nevada, 2003-12. The ratio consisted of the odds of the population increasing to that of decreasing. The dashed horizontal line represents a stable population. The solid line is overall average for the 10-year period (red=decrease, green=increase). The missing value in Bodie Hills (D) was based on a probability of decrease of zero. 


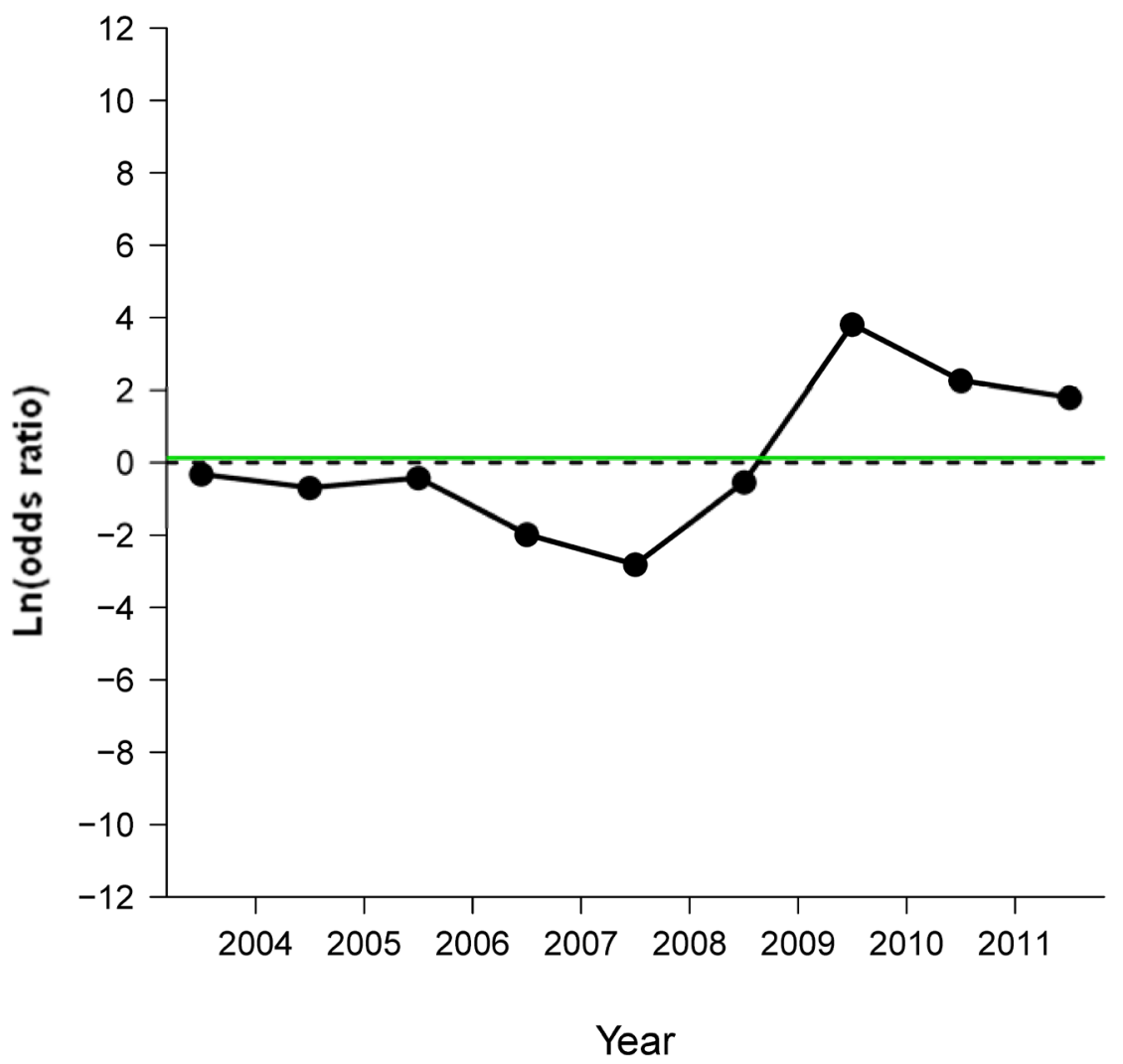

Figure 9. Graph showing In(odds ratio) of increase to decrease across all Bi-State Distinct Population Segment study area subpopulations, California and Nevada, 2003-12. The ratio consisted of the odds of the population increasing to that of decreasing. The dashed horizontal line represents a stable population. The solid green line is overall average for the 10 -year period. 
Table 2. Summary of posterior distributions of derived population vital rate parameters for greater sage-grouse (Centrocercus urophasianus) in the Bi-State Distinct Population Segment study area, California and Nevada, 2003-12.

\begin{tabular}{|c|c|c|c|c|}
\hline \multirow[b]{2}{*}{ Population vital rate } & \multirow[b]{2}{*}{ Age class } & \multicolumn{3}{|c|}{ Quantile $^{\mathrm{b}}$} \\
\hline & & 0.5 & 0.025 & 0.975 \\
\hline \multirow{2}{*}{ Nest propensity (np1) } & Adult & 0.96 & 0.91 & 0.99 \\
\hline & Yearling & 0.89 & 0.82 & 0.94 \\
\hline \multirow[t]{2}{*}{ Nest propensity (np2) } & Adult & 0.30 & 0.07 & 0.73 \\
\hline & Yearling & 0.18 & 0.01 & 0.77 \\
\hline \multirow[t]{2}{*}{ Nest survival (ns1) } & Adult & 0.42 & 0.21 & 0.64 \\
\hline & Yearling & 0.45 & 0.21 & 0.67 \\
\hline \multirow[t]{2}{*}{ Clutch size (cs1) } & Adult & 6.82 & 5.58 & 8.19 \\
\hline & Yearling & 6.50 & 5.17 & 8.00 \\
\hline \multirow[t]{2}{*}{ Nest survival (ns2) } & Adult & 0.45 & 0.04 & 0.90 \\
\hline & Yearling & 0.63 & 0.05 & 0.97 \\
\hline \multirow[t]{2}{*}{ Clutch size (cs2) } & Adult & 5.98 & 1.71 & 54.58 \\
\hline & Yearling & 7.37 & 1.68 & 78.92 \\
\hline \multirow[t]{2}{*}{ Hatchability } & Adult & 0.83 & 0.65 & 0.92 \\
\hline & Yearling & 0.89 & 0.74 & 0.96 \\
\hline \multirow[t]{2}{*}{ Chick survival } & Adult & 0.41 & 0.24 & 0.63 \\
\hline & Yearling & 0.34 & 0.18 & 0.57 \\
\hline \multirow[t]{2}{*}{ Fecundity } & Adult & 0.43 & 0.19 & 1.01 \\
\hline & Yearling & 0.37 & 0.13 & 1.56 \\
\hline \multirow[t]{3}{*}{ Survival } & Adult & 0.66 & 0.43 & 0.80 \\
\hline & Yearling & 0.66 & 0.43 & 0.81 \\
\hline & Juvenile & 0.78 & 0.71 & 0.85 \\
\hline
\end{tabular}

${ }^{a}$ Propensity of first nest and juvenile survival were derived from input from informative priors based on Taylor and others, 2012.

${ }^{\mathrm{b}}$ Median is 0.5 quantile and 95 percent credible interval is 0.025 quantile- 0.975 quantile.

Although short-term declining trends have been identified in many sage-grouse populations range-wide and outside of the Bi-State DPS (Connelly and others, 2004; Sage and Columbian Sharptailed Grouse Technical Committee, 2008; Garton and others, 2011), the findings here indicate that the Bi-State DPS overall is not experiencing similar declines. These results corroborate other population analyses conducted for sage-grouse specifically within the Bi-State subpopulations (Sage and Columbian Sharp-tailed Grouse Technical Committee, 2008; Garton and others, 2011). For example, estimation of $N$ and $\lambda$ reported here show a similar pattern to that estimated by Garton and others (2011) across the years of 2003-2007, when both analyses overlapped. Both analyses independently demonstrated consistency in $N$ (no change) during years 2003-2006, then a decline in $N$ between 2006 and 2007. The population reconstruction approach employed by Garton and others (2011) differed from those described here, in that the sole source of data for the previous study was lek counts. Furthermore, a mixed effects modeling approach using lek counts (Sage and Columbian Sharp-tailed Grouse Technical Committee, 2008) reached similar conclusions as the findings reported here and those of 
Garton and others (2011). Our modeling approach expands on previous analyses in multiple ways. First, we extend the period of investigation to include data from more recent years (2008-2012). When taking additional data into consideration, the period with the lowest population growth rate $(\lambda=0.84,95$-percent $\mathrm{CRI}=0.72-1.21)$ over the 10-years of investigation was 2007-08, whereas the highest growth rates followed those years (2009-2010, $\lambda=1.28,95$-percent $C R I=1.15-1.90)$ and all years since 2008 have experienced $\lambda$ greater than 1 . Second, the analytical approach used here integrates demographic data beyond raw lek counts (e.g., nesting and survival) to further inform $N$ and $\lambda$. This approach creates a more thorough understanding of population dynamics because $\lambda$ is a deterministic result of demographic rates and those data provide more information to estimate $\lambda$. Lastly, we provide data over a broader spatial scale which more appropriately represents population trend for the Bi-State DPS. Previous analyses (Sage and Columbian Sharp-tailed Grouse Technical Committee, 2008; Garton and others, 2011) relied on lek data from only two study areas, which were named Mono Lake and South Mono Lake, and correspond to Bodie Hills and Long Valley subpopulations, respectively. This study provided information on an additional 4 subpopulations that extend to borders of the DPS and data modeled here represent nearly all subpopulations within the DPS.

Several studies have indicated that sage-grouse populations have experienced long-term (i.e., decadal) declines in population sizes range-wide (Connelly and others, 2004; Sage and Columbian Sharp-tailed Grouse Technical Committee 2008; Garton and others, 2011). This study did not investigate population trends that exceed 10 years. The rationale for not including data prior to the 10 year period was two-fold. First, the lek data across the Bi-State DPS did not meet high enough quality standards to allow for reliable inferences for this specific analysis prior to this 10-year period. For example, many lek locations were unknown, or believed non-existent, within the majority of subpopulations and thus not counted. The population reconstruction approach employed by Garton and others (2011) evaluated trends across periods that date back to 1965 within two areas (i.e., Mono Lake and South Mono Lake). The study concluded that no consistent long-term trend was detected at either area over 40 years (Garton and others, 2011). However, the confidence intervals in the first few decades were relatively wide. Second, demographic data was not available for any subpopulation during years prior to 2003, which are fundamental modeling components of this study. Nevertheless, the objective of this study was not to compare to historic levels but instead to reliably estimate if current population size is decreasing, stable, or increasing. A 10-year period was sufficient to reliably estimate trends, while accounting for the cyclic nature of sage-grouse populations. For example, sage-grouse generally exhibit a degree of short-term oscillation in population that has a regular period of 6-9 years (Fedy and others, 2013). Thus, 10-years will fully encompass the cyclicity, whereas estimates from a shorter term period might be misleading in only capturing a portion of the cycle. However, although the 10-year period we evaluated represented climatic variation that might influence population dynamics, a period of severe and prolonged drought did not occur in this time. Thus, the effects of drought on sage-grouse population trends are uncertain for the Bi-State and studies that investigate these effects would be beneficial

This report provides results for the first of three steps of a comprehensive population dynamics analysis for the Bi-State DPS. As mentioned above, in a second step, a retrospective analysis that evaluates the relative importance of specific population vital rates to $\lambda$ will be conducted to further understand those life-stages that regulate changes in population size. As a prospective analysis, sensitivities and elasticities for each population vital rate will also be calculated. A final step will entail linking environmental factors (e.g., climatic variables) to the derived population demographic parameters and $\lambda \mathrm{s}$. Individually and collectively, these analyses should be useful in the decision-making process for land stewards, managers, and policy-makers within the Bi-State DPS. 


\section{Acknowledgments}

We are indebted to the many biologists and technicians who spent countless hours capturing and tracking radio-marked sage-grouse and conducting lek counts that made this modeling effort possible, especially M. Farinha and E. Kolada. We thank the Bi-State Technical Advisory Committee and the BiState Executive Oversight Committee for recognizing the need for this research and providing support. In particular, we thank T. Koch, S. Abele, and R. Kearney from the U. S. Fish and Wildlife Service; S. Espinosa, T. Wasley, and J. Tull from the Nevada Department of Wildlife; S. Nelson, S. Lisius, P. Ziegler, and A Lueders from the Bureau of Land Management; T. Taylor from California Department of Fish and Wildlife; J. Sedinger from University of Nevada Reno; and D. Delehanty from Idaho State University. We also thank D. Blankenship, D. Racine, J. Fatooh, A. Halford R. Haldeman, L. Fields, and D. House. Excellent reviews by J. Yee, T. Edwards, C. Hagen, T. Kimball, and K. Miles greatly improved this manuscript. This work was a collaborative effort between California Department of Fish and Wildlife, Nevada Department of Wildlife, University of Idaho, University of Nevada Reno, U. S. Fish and Wildlife Service, Bureau of Land Management, U. S. Department of Agriculture Forest Service, Los Angeles Department of Water and Power, and Quail Unlimited.

\section{References Cited}

Atamian, M.T., and Sedinger, J.S., 2010, Balanced sex ratio at hatch in a greater sage-grouse (Centrocercus urophasianus) population: The Auk, v. 127, p. 16-22.

Benedict, N.G., Oyler-McCance, S.J., Taylor, S.E., Braun, C.E., and Quinn, T.W., 2003, Evaluation of the eastern (Centrocercus urophasianus urophasianus) and western (Centrocercus urophasianus phaios) subspecies of sage-grouse using mitochondrial control-region sequence data: Conservation Genetics, v. 4, p. 301-310.

Caswell, H., 2001, Matrix population models, second edition: Sunderland, Massachusetts, Sinauer Associates, p. 710.

Connelly, J.W., Reese, K.P., and Schroeder, M.A., 2003, Monitoring of greater sage-grouse habitats and populations: Moscow, University of Idaho, College of Natural Resources Experiment Station, Station Bulletin 80 .

Fedy, B.C., and Aldridge C.L., 2011, The importance of within-year repeated counts and the influence of scale on long-term monitoring of sage-grouse: Journal of Wildlife Management, v. 75, p. $1022-1033$.

Garton, E.O., Connelly, J.W., Horne, J.S., Hagen, C.A., Moser, A., and Schroeder, M., 2011, Greater sage-grouse population dynamics and probability of persistence, in Knick, S.T., and Connelly, J.W., eds., Greater sage-grouse - Ecology and conservation of a landscape species and its habitats: Studies in Avian Biology, no. 38, Berkeley, California, University of California Press, p. 293-382.

Giesen, K.M., Schoenberg, T.J., and Braun, C.E., 1982, Methods for trapping sage grouse in Colorado: Wildlife Society Bulletin, v. 10, p. 224-231.

Gotelli, N.J., and Ellison, A.M., 2004, A Primer of Ecological Statistics, Sunderland, Massachusetts, Sinauer Associates Inc., p. 479. 
Kéry, M., and Schaub, M., 2012, Bayesian population analysis using WinBUGS-A hierarchical perspective: San Diego, Academic Press, p. 535.

Knick, S., and Connelly, J.W., eds., 2011, Greater sage-grouse-Ecology and conservation of a landscape species and its habitats: Studies in Avian Biology, no. 38, Berkeley, California, University of California Press, p. xi-xii.

Kolada, E.J., Sedinger, J.S., and Casazza, M.L., 2009, Nest site selection by greater sage-grouse in Mono County, California: Journal of Wildlife Management, v. 73, p. 1,333-1,340.

Oyler-McCance, S.J., Taylor, S.E., and Quinn, T.W., 2005, A multilocus population genetic survey of the greater sage-grouse across their range: Molecular Ecology, v. 14, p. 1,293-1,310.

Oyler-McCance, S.J., Casazza, J.A., Fike, J.A., and Coates, P.S., in press, Hierarchical spatial genetic structure in a distinct population segment of greater sage-grouse: Conservation Genetics.

Sage and Columbian Sharp-tailed Grouse Technical Committee, 2008, Greater sage-grouse trends: an analysis of lek count databases 1965-2007: Western Association of Fish and Wildlife Agencies, Cheyenne, Wyoming.

Schroeder, M.A., Aldridge, C.L., Apa, A.D., Bohne, J.R., Braun, C.E., Bunnell, S.D., Connelly, J.W., Deibert, P.A., Gardner, S.C., Hilliard, M.A., Kobriger, G.D., McAdam, S.M., McCarthy, C.W., McCarthy, J.J., Mitchell, D.L., Rickerson, E.V., and Stiver, S.J., 2004, Distribution of sage-grouse in North America: Condor, v. 106, p. 363-376.

Taylor, R.L., Walker, B.L., Naugle, D.E., and Mills, L.S., 2012, Managing multiple vital rates to maximize greater sage-grouse population growth: The Journal of Wildlife Management, v. 76, p. 336-347.

U.S. Department of the Interior, 2010, 12-month findings for petitions to list the greater sage-grouse (Centrocercus urophasianus) as threatened or endangered: Federal Register, 50 CFR Part 17.

Wakkinen, W.L., Reese, K.P., Connelly, J.W., and Fischer, R.A., 1992, An improved spotlighting technique for capturing sage-grouse: Wildlife Society Bulletin, v. 20, p. 425-426.

Zuur, A.F., Ieno, E.N., Walker, N.J., Saveliev, A.A., and Smith, G.M., 2009, Mixed effects models and extensions in ecology with R: New York, Springer-Verlag, p. 574. 


\section{Appendix A. Summary of Derived Posterior Distributions for Greater Sage- Grouse (Centrocercus urophasianus) Population Vital Rates by Subpopulation within the Bi-State Distinct Population Segment Study Area, 2003-12.}

\begin{tabular}{|c|c|c|c|c|c|}
\hline \multirow{2}{*}{ Subpopulationa } & \multirow[b]{2}{*}{ Vital rate } & \multirow[b]{2}{*}{ Age } & \multicolumn{3}{|c|}{ Quantileb $^{b}$} \\
\hline & & & 0.5 & 0.025 & 0.975 \\
\hline- & Nesting propensity (np1) & Adult & 0.96 & 0.91 & 0.99 \\
\hline- & Nesting propensity (np1) & Yearling & 0.89 & 0.82 & 0.94 \\
\hline- & Survival & Juvenile & 0.78 & 0.71 & 0.85 \\
\hline \multirow[t]{18}{*}{ Pine Nut } & Nesting propensity (np2) & Adult & 0.23 & 0.00 & 0.70 \\
\hline & & Yearling & 0.04 & 0.00 & 0.55 \\
\hline & Nest survival (ns1) & Adult & 0.44 & 0.21 & 0.67 \\
\hline & & Yearling & 0.46 & 0.22 & 0.68 \\
\hline & Clutch size (cs1) & Adult & 6.70 & 5.18 & 8.07 \\
\hline & & Yearling & 6.37 & 4.87 & 7.89 \\
\hline & Nest survival (ns2) & Adult & 0.45 & 0.00 & 0.95 \\
\hline & & Yearling & 0.63 & 0.00 & 0.98 \\
\hline & Clutch size (cs2) & Adult & 6.07 & 0.62 & 57.62 \\
\hline & & Yearling & 7.52 & 0.63 & 87.17 \\
\hline & Hatchability & Adult & 0.90 & 0.65 & 0.98 \\
\hline & & Yearling & 0.95 & 0.77 & 0.99 \\
\hline & Chick survival & Adult & 0.42 & 0.24 & 0.70 \\
\hline & & Yearling & 0.35 & 0.17 & 0.64 \\
\hline & Fecundity & Adult & 0.47 & 0.19 & 1.00 \\
\hline & & Yearling & 0.36 & 0.13 & 0.93 \\
\hline & Survival & Adult & 0.70 & 0.54 & 0.84 \\
\hline & & Yearling & 0.70 & 0.53 & 0.85 \\
\hline \multirow[t]{18}{*}{ Desert Creek } & Nesting propensity (np2) & Adult & 0.35 & 0.06 & 0.83 \\
\hline & & Yearling & 0.09 & 0.00 & 0.80 \\
\hline & Nest survival (ns1) & Adult & 0.46 & 0.24 & 0.69 \\
\hline & & Yearling & 0.48 & 0.24 & 0.72 \\
\hline & Clutch size (cs1) & Adult & 6.93 & 5.72 & 8.44 \\
\hline & & Yearling & 6.60 & 5.29 & 8.18 \\
\hline & Nest survival (ns2) & Adult & 0.50 & 0.05 & 0.93 \\
\hline & & Yearling & 0.67 & 0.08 & 0.98 \\
\hline & Clutch size (cs2) & Adult & 6.24 & 0.66 & 48.34 \\
\hline & & Yearling & 7.83 & 0.75 & 70.80 \\
\hline & Hatchability & Adult & 0.91 & 0.75 & 0.97 \\
\hline & & Yearling & 0.96 & 0.84 & 0.99 \\
\hline & Chick survival & Adult & 0.41 & 0.25 & 0.61 \\
\hline & & Yearling & 0.34 & 0.18 & 0.56 \\
\hline & Fecundity & Adult & 0.53 & 0.25 & 1.16 \\
\hline & & Yearling & 0.40 & 0.15 & 1.13 \\
\hline & Survival & Adult & 0.68 & 0.51 & 0.81 \\
\hline & & Yearling & 0.68 & 0.51 & 0.82 \\
\hline
\end{tabular}




\begin{tabular}{|c|c|c|c|c|c|}
\hline \multirow[b]{2}{*}{ Subpopulationa } & \multirow[b]{2}{*}{ Vital rate } & \multirow[b]{2}{*}{ Age } & \multicolumn{3}{|c|}{ Quantile $^{b}$} \\
\hline & & & 0.5 & 0.025 & 0.975 \\
\hline \multirow[t]{18}{*}{ Fales } & \multirow[t]{2}{*}{ Nesting propensity (np2) } & Adult & 0.24 & 0.00 & 0.72 \\
\hline & & Yearling & 0.35 & 0.02 & 0.96 \\
\hline & \multirow[t]{2}{*}{ Nest survival (ns1) } & Adult & 0.41 & 0.17 & 0.65 \\
\hline & & Yearling & 0.43 & 0.16 & 0.66 \\
\hline & \multirow[t]{2}{*}{ Clutch size (cs1) } & Adult & 6.81 & 5.54 & 8.34 \\
\hline & & Yearling & 6.49 & 5.18 & 8.07 \\
\hline & \multirow[t]{2}{*}{ Nest survival (ns2) } & Adult & 0.38 & 0.00 & 0.89 \\
\hline & & Yearling & 0.55 & 0.00 & 0.96 \\
\hline & \multirow[t]{2}{*}{ Clutch size (cs2) } & Adult & 6.36 & 1.02 & 155.31 \\
\hline & & Yearling & 7.97 & 1.11 & 199.36 \\
\hline & \multirow[t]{2}{*}{ Hatchability } & Adult & 0.93 & 0.72 & 0.99 \\
\hline & & Yearling & 0.97 & 0.83 & 0.99 \\
\hline & \multirow[t]{2}{*}{ Chick survival } & Adult & 0.45 & 0.27 & 0.69 \\
\hline & & Yearling & 0.38 & 0.20 & 0.63 \\
\hline & \multirow[t]{2}{*}{ Fecundity } & Adult & 0.50 & 0.20 & 1.72 \\
\hline & & Yearling & 0.49 & 0.16 & 4.65 \\
\hline & \multirow[t]{2}{*}{ Survival } & Adult & 0.58 & 0.03 & 0.76 \\
\hline & & Yearling & 0.57 & 0.04 & 0.76 \\
\hline \multirow[t]{18}{*}{ Bodie Hills } & \multirow[t]{2}{*}{ Nesting propensity (np2) } & Adult & 0.33 & 0.12 & 0.70 \\
\hline & & Yearling & 0.31 & 0.04 & 0.83 \\
\hline & \multirow[t]{2}{*}{ Nest survival (ns1) } & Adult & 0.46 & 0.27 & 0.65 \\
\hline & & Yearling & 0.48 & 0.27 & 0.68 \\
\hline & \multirow[t]{2}{*}{ Clutch size (cs1) } & Adult & 6.76 & 5.66 & 8.00 \\
\hline & & Yearling & 6.44 & 5.20 & 7.83 \\
\hline & \multirow[t]{2}{*}{ Nest survival (ns2) } & Adult & 0.50 & 0.08 & 0.89 \\
\hline & & Yearling & 0.67 & 0.11 & 0.96 \\
\hline & \multirow[t]{2}{*}{ Clutch size (cs2) } & Adult & 6.17 & 3.04 & 23.87 \\
\hline & & Yearling & 7.49 & 2.72 & 42.80 \\
\hline & \multirow[t]{2}{*}{ Hatchability } & Adult & 0.93 & 0.80 & 0.98 \\
\hline & & Yearling & 0.97 & 0.87 & 0.99 \\
\hline & \multirow[t]{2}{*}{ Chick survival } & Adult & 0.38 & 0.23 & 0.57 \\
\hline & & Yearling & 0.31 & 0.17 & 0.51 \\
\hline & \multirow[t]{2}{*}{ Fecundity } & Adult & 0.49 & 0.25 & 0.90 \\
\hline & & Yearling & 0.42 & 0.17 & 1.17 \\
\hline & Survival & Adult & 0.65 & 0.50 & 0.78 \\
\hline & & Yearling & 0.65 & 0.49 & 0.79 \\
\hline Parker Meadows & Nesting propensity (np2) & Adult & 0.24 & 0.07 & 0.63 \\
\hline & & Yearling & 0.07 & 0.00 & 0.73 \\
\hline & Nest survival (ns1) & Adult & 0.41 & 0.20 & 0.63 \\
\hline & & Yearling & 0.43 & 0.19 & 0.65 \\
\hline & Clutch size (cs1) & Adult & 6.72 & 5.49 & 8.07 \\
\hline & & Yearling & 6.41 & 5.07 & 7.86 \\
\hline & Nest Survival (ns2) & Adult & 0.41 & 0.01 & 0.87 \\
\hline & & Yearling & 0.60 & 0.02 & 0.96 \\
\hline
\end{tabular}




\begin{tabular}{|c|c|c|c|c|c|}
\hline \multirow{2}{*}{ Subpopulationa } & \multirow[b]{2}{*}{ Vital rate } & \multirow[b]{2}{*}{ Age } & \multicolumn{3}{|c|}{ Quantileb } \\
\hline & & & 0.5 & 0.025 & 0.975 \\
\hline \multirow{28}{*}{ Long Valley } & \multirow[t]{2}{*}{ Clutch Size (cs2) } & Adult & 5.34 & 2.17 & 20.89 \\
\hline & & Yearling & 6.39 & 2.13 & 37.33 \\
\hline & \multirow[t]{2}{*}{ Hatchability } & Adult & 0.34 & 0.15 & 0.61 \\
\hline & & Yearling & 0.51 & 0.24 & 0.78 \\
\hline & \multirow[t]{2}{*}{ Chick Survival } & Adult & 0.40 & 0.23 & 0.61 \\
\hline & & Yearling & 0.33 & 0.17 & 0.55 \\
\hline & \multirow[t]{2}{*}{ Fecundity } & Adult & 0.15 & 0.06 & 0.39 \\
\hline & & Yearling & 0.17 & 0.05 & 0.49 \\
\hline & \multirow[t]{2}{*}{ Survival } & Adult & 0.67 & 0.47 & 0.80 \\
\hline & & Yearling & 0.66 & 0.47 & 0.81 \\
\hline & \multirow[t]{2}{*}{ Nesting propensity (np2) } & Adult & 0.45 & 0.18 & 0.80 \\
\hline & & Yearling & 0.21 & 0.02 & 0.73 \\
\hline & \multirow[t]{2}{*}{ Nest Survival (ns1) } & Adult & 0.37 & 0.18 & 0.56 \\
\hline & & Yearling & 0.39 & 0.16 & 0.60 \\
\hline & \multirow[t]{2}{*}{ Clutch Size (cs1) } & Adult & 7.00 & 5.90 & 8.25 \\
\hline & & Yearling & 6.67 & 5.39 & 8.16 \\
\hline & \multirow[t]{2}{*}{ Nest Survival (ns2) } & Adult & 0.45 & 0.08 & 0.86 \\
\hline & & Yearling & 0.64 & 0.08 & 0.96 \\
\hline & \multirow[t]{2}{*}{ Clutch Size (cs2) } & Adult & 5.71 & 2.74 & 21.42 \\
\hline & & Yearling & 7.02 & 2.75 & 36.04 \\
\hline & \multirow[t]{2}{*}{ Hatchability } & Adult & 0.94 & 0.82 & 0.98 \\
\hline & & Yearling & 0.97 & 0.88 & 0.99 \\
\hline & \multirow[t]{2}{*}{ Chick Survival } & Adult & 0.40 & 0.24 & 0.58 \\
\hline & & Yearling & 0.33 & 0.18 & 0.54 \\
\hline & \multirow[t]{2}{*}{ Fecundity } & Adult & 0.46 & 0.22 & 0.92 \\
\hline & & Yearling & 0.36 & 0.13 & 0.99 \\
\hline & \multirow[t]{2}{*}{ Survival } & Adult & 0.68 & 0.54 & 0.80 \\
\hline & & Yearling & 0.68 & 0.52 & 0.81 \\
\hline
\end{tabular}

${ }^{\mathrm{a}} \mathrm{A}$ constant rate across the Bi-State Distinct Population Segment study area was assumed for those population vital rates without a subpopulation listed. Propensity of first nest and juvenile survival were derived from input from informative priors based on Taylor and others, 2012.

${ }^{\mathrm{b}}$ Median is 0.5 quantile and 95 percent credible interval is 0.025 quantile -0.975 quantile. 


\section{Appendix B. Summary of Derived Posterior Distributions for Greater Sage- Grouse (Centrocercus urophasianus)Population Vital Rates by Year, 2003-12.}

\begin{tabular}{|c|c|c|c|c|c|}
\hline \multirow[b]{2}{*}{ Vital rate } & \multirow[b]{2}{*}{ Age } & \multirow[b]{2}{*}{ Year } & \multicolumn{3}{|c|}{ Quantileb $^{b}$} \\
\hline & & & 50 & 2.5 & 97.5 \\
\hline Nesting propensity (np1) & Adult & - & 0.96 & 0.91 & 0.99 \\
\hline Nesting propensity (np1) & Yearling & - & 0.89 & 0.82 & 0.94 \\
\hline \multirow[t]{10}{*}{ Nesting propensity (np2) } & Adult & 2003 & 0.26 & 0.04 & 0.70 \\
\hline & & 2004 & 0.24 & 0.05 & 0.62 \\
\hline & & 2005 & 0.21 & 0.03 & 0.62 \\
\hline & & 2006 & 0.25 & 0.00 & 0.93 \\
\hline & & 2007 & 0.12 & 0.00 & 0.62 \\
\hline & & 2008 & 0.29 & 0.07 & 0.66 \\
\hline & & 2009 & 0.25 & 0.04 & 0.67 \\
\hline & & 2010 & 0.66 & 0.25 & 0.91 \\
\hline & & 2011 & 0.65 & 0.24 & 0.92 \\
\hline & & 2012 & 0.14 & 0.00 & 0.66 \\
\hline \multirow[t]{10}{*}{ Nesting propensity (np2) } & Yearling & 2003 & 0.17 & 0.01 & 0.73 \\
\hline & & 2004 & 0.15 & 0.01 & 0.72 \\
\hline & & 2005 & 0.30 & 0.04 & 0.86 \\
\hline & & 2006 & 0.16 & 0.00 & 0.94 \\
\hline & & 2007 & 0.09 & 0.00 & 0.64 \\
\hline & & 2008 & 0.28 & 0.04 & 0.88 \\
\hline & & 2009 & 0.07 & 0.00 & 0.53 \\
\hline & & 2010 & 0.12 & 0.00 & 0.69 \\
\hline & & 2011 & 0.31 & 0.03 & 0.94 \\
\hline & & 2012 & 0.11 & 0.00 & 0.76 \\
\hline \multirow[t]{10}{*}{ Nest survival (ns1) } & Adult & 2003 & 0.39 & 0.16 & 0.59 \\
\hline & & 2004 & 0.41 & 0.22 & 0.61 \\
\hline & & 2005 & 0.42 & 0.23 & 0.62 \\
\hline & & 2006 & 0.41 & 0.14 & 0.67 \\
\hline & & 2007 & 0.45 & 0.24 & 0.69 \\
\hline & & 2008 & 0.41 & 0.21 & 0.61 \\
\hline & & 2009 & 0.48 & 0.29 & 0.71 \\
\hline & & 2010 & 0.44 & 0.25 & 0.65 \\
\hline & & 2011 & 0.41 & 0.19 & 0.62 \\
\hline & & 2012 & 0.42 & 0.21 & 0.66 \\
\hline \multirow[t]{10}{*}{ Nest survival (ns1) } & Yearling & 2003 & 0.41 & 0.15 & 0.63 \\
\hline & & 2004 & 0.43 & 0.22 & 0.64 \\
\hline & & 2005 & 0.44 & 0.21 & 0.65 \\
\hline & & 2006 & 0.44 & 0.13 & 0.69 \\
\hline & & 2007 & 0.47 & 0.24 & 0.71 \\
\hline & & 2008 & 0.43 & 0.19 & 0.63 \\
\hline & & 2009 & 0.50 & 0.29 & 0.72 \\
\hline & & 2010 & 0.47 & 0.24 & 0.68 \\
\hline & & 2011 & 0.43 & 0.18 & 0.65 \\
\hline & & 2012 & 0.44 & 0.21 & 0.68 \\
\hline
\end{tabular}




\begin{tabular}{|c|c|c|c|c|c|}
\hline \multirow[b]{2}{*}{ Vital rate ${ }^{a}$} & \multirow[b]{2}{*}{ Age } & \multirow[b]{2}{*}{ Year } & \multicolumn{3}{|c|}{ Quantileb $^{b}$} \\
\hline & & & 50 & 2.5 & 97.5 \\
\hline \multirow[t]{10}{*}{ Clutch size (cs1) } & \multirow[t]{10}{*}{ Adult } & 2003 & 7.11 & 6.03 & 8.50 \\
\hline & & 2004 & 6.44 & 5.44 & 7.41 \\
\hline & & 2005 & 6.26 & 5.05 & 7.32 \\
\hline & & 2006 & 6.76 & 5.11 & 8.72 \\
\hline & & 2007 & 6.76 & 5.32 & 8.31 \\
\hline & & 2008 & 7.19 & 6.04 & 8.59 \\
\hline & & 2009 & 7.01 & 5.91 & 8.31 \\
\hline & & 2010 & 7.08 & 5.99 & 8.38 \\
\hline & & 2011 & 6.91 & 5.73 & 8.32 \\
\hline & & 2012 & 6.68 & 5.20 & 8.08 \\
\hline \multirow[t]{10}{*}{ Clutch size (cs1) } & \multirow[t]{10}{*}{ Yearling } & 2003 & 6.80 & 5.56 & 8.22 \\
\hline & & 2004 & 6.13 & 4.95 & 7.43 \\
\hline & & 2005 & 5.97 & 4.62 & 7.35 \\
\hline & & 2006 & 6.44 & 4.76 & 8.42 \\
\hline & & 2007 & 6.43 & 5.10 & 7.88 \\
\hline & & 2008 & 6.86 & 5.58 & 8.39 \\
\hline & & 2009 & 6.67 & 5.54 & 7.97 \\
\hline & & 2010 & 6.74 & 5.54 & 8.25 \\
\hline & & 2011 & 6.58 & 5.25 & 8.19 \\
\hline & & 2012 & 6.36 & 4.78 & 7.89 \\
\hline \multirow[t]{10}{*}{ Nest survival (ns2) } & \multirow[t]{10}{*}{ Adult } & 2003 & 0.09 & 0.00 & 0.73 \\
\hline & & 2004 & 0.37 & 0.02 & 0.84 \\
\hline & & 2005 & 0.50 & 0.05 & 0.90 \\
\hline & & 2006 & 0.43 & 0.00 & 0.97 \\
\hline & & 2007 & 0.47 & 0.00 & 0.96 \\
\hline & & 2008 & 0.70 & 0.15 & 0.96 \\
\hline & & 2009 & 0.52 & 0.05 & 0.93 \\
\hline & & 2010 & 0.41 & 0.05 & 0.83 \\
\hline & & 2011 & 0.51 & 0.07 & 0.89 \\
\hline & & 2012 & 0.46 & 0.00 & 0.97 \\
\hline \multirow[t]{10}{*}{ Nest survival (ns2) } & \multirow[t]{10}{*}{ Yearling } & 2003 & 0.26 & 0.00 & 0.89 \\
\hline & & 2004 & 0.57 & 0.04 & 0.95 \\
\hline & & 2005 & 0.69 & 0.09 & 0.97 \\
\hline & & 2006 & 0.61 & 0.00 & 0.99 \\
\hline & & 2007 & 0.65 & 0.00 & 0.99 \\
\hline & & 2008 & 0.83 & 0.16 & 0.99 \\
\hline & & 2009 & 0.71 & 0.06 & 0.98 \\
\hline & & 2010 & 0.61 & 0.04 & 0.96 \\
\hline & & 2011 & 0.70 & 0.09 & 0.97 \\
\hline & & 2012 & 0.64 & 0.00 & 0.99 \\
\hline
\end{tabular}




\begin{tabular}{|c|c|c|c|c|c|}
\hline \multirow[b]{2}{*}{ Vital rate ${ }^{a}$} & \multirow[b]{2}{*}{ Age } & \multirow[b]{2}{*}{ Year } & \multicolumn{3}{|c|}{ Quantile $^{b}$} \\
\hline & & & 50 & 2.5 & 97.5 \\
\hline \multirow[t]{10}{*}{ Clutch size (cs2) } & \multirow[t]{10}{*}{ Adult } & 2003 & 6.33 & 1.74 & 110.00 \\
\hline & & 2004 & 6.09 & 1.40 & 55.21 \\
\hline & & 2005 & 6.22 & 1.59 & 60.69 \\
\hline & & 2006 & 5.89 & 0.93 & 51.40 \\
\hline & & 2007 & 6.05 & 1.18 & 59.38 \\
\hline & & 2008 & 5.98 & 2.39 & 40.39 \\
\hline & & 2009 & 6.03 & 2.24 & 39.38 \\
\hline & & 2010 & 6.10 & 2.56 & 38.88 \\
\hline & & 2011 & 5.10 & 1.93 & 33.57 \\
\hline & & 2012 & 6.02 & 1.14 & 56.85 \\
\hline \multirow[t]{10}{*}{ Clutch size (cs2) } & \multirow[t]{10}{*}{ Yearling } & 2003 & 7.83 & 1.74 & 163.05 \\
\hline & & 2004 & 7.46 & 1.55 & 74.84 \\
\hline & & 2005 & 7.79 & 1.61 & 86.55 \\
\hline & & 2006 & 7.04 & 1.17 & 68.25 \\
\hline & & 2007 & 7.48 & 1.40 & 89.66 \\
\hline & & 2008 & 7.34 & 2.01 & 59.44 \\
\hline & & 2009 & 7.49 & 1.98 & 57.50 \\
\hline & & 2010 & 7.61 & 2.13 & 59.12 \\
\hline & & 2011 & 6.34 & 1.98 & 46.12 \\
\hline & & 2012 & 7.34 & 1.24 & 84.64 \\
\hline \multirow[t]{10}{*}{ Hatchability } & \multirow[t]{10}{*}{ Adult } & 2003 & 0.85 & 0.72 & 0.94 \\
\hline & & 2004 & 0.77 & 0.62 & 0.86 \\
\hline & & 2005 & 0.79 & 0.65 & 0.87 \\
\hline & & 2006 & 0.82 & 0.39 & 0.97 \\
\hline & & 2007 & 0.88 & 0.70 & 0.98 \\
\hline & & 2008 & 0.87 & 0.76 & 0.95 \\
\hline & & 2009 & 0.92 & 0.84 & 0.96 \\
\hline & & 2010 & 0.74 & 0.58 & 0.84 \\
\hline & & 2011 & 0.79 & 0.63 & 0.88 \\
\hline & & 2012 & 0.82 & 0.60 & 0.93 \\
\hline \multirow[t]{10}{*}{ Hatchability } & \multirow[t]{10}{*}{ Yearling } & 2003 & 0.91 & 0.80 & 0.97 \\
\hline & & 2004 & 0.84 & 0.70 & 0.92 \\
\hline & & 2005 & 0.86 & 0.73 & 0.93 \\
\hline & & 2006 & 0.88 & 0.51 & 0.98 \\
\hline & & 2007 & 0.93 & 0.80 & 0.99 \\
\hline & & 2008 & 0.92 & 0.83 & 0.97 \\
\hline & & 2009 & 0.95 & 0.90 & 0.98 \\
\hline & & 2010 & 0.83 & 0.67 & 0.91 \\
\hline & & 2011 & 0.86 & 0.73 & 0.93 \\
\hline & & 2012 & 0.88 & 0.70 & 0.97 \\
\hline
\end{tabular}




\begin{tabular}{|c|c|c|c|c|c|}
\hline \multirow[b]{2}{*}{ Vital rate } & \multirow[b]{2}{*}{ Age } & \multirow[b]{2}{*}{ Year } & \multicolumn{3}{|c|}{ Quantileb $^{b}$} \\
\hline & & & 50 & 2.5 & 97.5 \\
\hline \multirow[t]{10}{*}{ Chick survival } & \multirow[t]{10}{*}{ Adult } & 2003 & 0.53 & 0.39 & 0.69 \\
\hline & & 2004 & 0.46 & 0.35 & 0.60 \\
\hline & & 2005 & 0.39 & 0.29 & 0.52 \\
\hline & & 2006 & 0.36 & 0.10 & 0.67 \\
\hline & & 2007 & 0.32 & 0.16 & 0.52 \\
\hline & & 2008 & 0.32 & 0.21 & 0.47 \\
\hline & & 2009 & 0.58 & 0.34 & 0.91 \\
\hline & & 2010 & 0.41 & 0.29 & 0.57 \\
\hline & & 2011 & 0.33 & 0.19 & 0.51 \\
\hline & & 2012 & 0.41 & 0.12 & 0.80 \\
\hline \multirow[t]{10}{*}{ Chick survival } & \multirow[t]{10}{*}{ Yearling } & 2003 & 0.45 & 0.30 & 0.62 \\
\hline & & 2004 & 0.39 & 0.27 & 0.54 \\
\hline & & 2005 & 0.31 & 0.19 & 0.49 \\
\hline & & 2006 & 0.29 & 0.07 & 0.59 \\
\hline & & 2007 & 0.25 & 0.13 & 0.44 \\
\hline & & 2008 & 0.25 & 0.14 & 0.43 \\
\hline & & 2009 & 0.50 & 0.26 & 0.87 \\
\hline & & 2010 & 0.34 & 0.20 & 0.52 \\
\hline & & 2011 & 0.27 & 0.13 & 0.45 \\
\hline & & 2012 & 0.34 & 0.08 & 0.75 \\
\hline \multirow[t]{10}{*}{ Fecundity } & \multirow[t]{10}{*}{ Adult } & 2003 & 0.52 & 0.24 & 1.32 \\
\hline & & 2004 & 0.41 & 0.21 & 0.84 \\
\hline & & 2005 & 0.36 & 0.19 & 0.81 \\
\hline & & 2006 & 0.33 & 0.06 & 0.87 \\
\hline & & 2007 & 0.34 & 0.14 & 0.76 \\
\hline & & 2008 & 0.38 & 0.19 & 0.87 \\
\hline & & 2009 & 0.76 & 0.39 & 1.49 \\
\hline & & 2010 & 0.48 & 0.26 & 1.13 \\
\hline & & 2011 & 0.37 & 0.17 & 0.95 \\
\hline & & 2012 & 0.37 & 0.10 & 1.10 \\
\hline \multirow[t]{10}{*}{ Fecundity } & \multirow[t]{10}{*}{ Yearling } & 2003 & 0.46 & 0.17 & 2.61 \\
\hline & & 2004 & 0.36 & 0.16 & 1.27 \\
\hline & & 2005 & 0.35 & 0.14 & 2.08 \\
\hline & & 2006 & 0.28 & 0.05 & 1.24 \\
\hline & & 2007 & 0.28 & 0.10 & 1.20 \\
\hline & & 2008 & 0.33 & 0.13 & 1.59 \\
\hline & & 2009 & 0.62 & 0.27 & 1.77 \\
\hline & & 2010 & 0.35 & 0.15 & 1.12 \\
\hline & & 2011 & 0.30 & 0.10 & 1.10 \\
\hline & & 2012 & 0.33 & 0.07 & 1.64 \\
\hline
\end{tabular}




\begin{tabular}{|c|c|c|c|c|c|}
\hline \multirow[b]{2}{*}{ Vital rate ${ }^{a}$} & \multirow[b]{2}{*}{ Age } & \multirow[b]{2}{*}{ Year } & \multicolumn{3}{|c|}{ Quantile $^{b}$} \\
\hline & & & 50 & 2.5 & 97.5 \\
\hline \multirow[t]{10}{*}{ Survival } & Adult & 2003 & 0.60 & 0.36 & 0.75 \\
\hline & & 2004 & 0.66 & 0.46 & 0.78 \\
\hline & & 2005 & 0.67 & 0.45 & 0.79 \\
\hline & & 2006 & 0.65 & 0.39 & 0.83 \\
\hline & & 2007 & 0.58 & 0.35 & 0.74 \\
\hline & & 2008 & 0.60 & 0.39 & 0.74 \\
\hline & & 2009 & 0.72 & 0.51 & 0.85 \\
\hline & & 2010 & 0.72 & 0.50 & 0.85 \\
\hline & & 2011 & 0.75 & 0.53 & 0.88 \\
\hline & & 2012 & 0.65 & 0.39 & 0.80 \\
\hline \multirow[t]{10}{*}{ Survival } & Yearling & 2003 & 0.60 & 0.36 & 0.75 \\
\hline & & 2004 & 0.65 & 0.44 & 0.79 \\
\hline & & 2005 & 0.66 & 0.44 & 0.80 \\
\hline & & 2006 & 0.65 & 0.39 & 0.83 \\
\hline & & 2007 & 0.58 & 0.36 & 0.74 \\
\hline & & 2008 & 0.60 & 0.36 & 0.75 \\
\hline & & 2009 & 0.72 & 0.51 & 0.85 \\
\hline & & 2010 & 0.72 & 0.50 & 0.85 \\
\hline & & 2011 & 0.75 & 0.52 & 0.88 \\
\hline & & 2012 & 0.65 & 0.38 & 0.81 \\
\hline Survival & Juvenile & - & 0.78 & 0.71 & 0.85 \\
\hline
\end{tabular}

${ }^{\text {a }}$ Propensity of first nest and juvenile survival were derived from input from informative priors based on Taylor and others, 2012.

${ }^{\mathrm{b}}$ Median is 0.5 quantile and 95 percent credible interval is 0.025 quantile- 0.975 quantile. 
Publishing support provided by the U.S. Geological Survey

Publishing Network, Tacoma Publishing Service Center

For more information concerning the research in this report, contact the Director, Western Ecological Research Center

U.S. Geological Survey

3020 State University Drive East

Sacramento, California 95819

http://werc.usgs.gov/ 
을

홍

$\overline{\bar{\Xi}}$

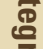

สำ

$\frac{2}{7}$

음

을

ธิ

음

5 